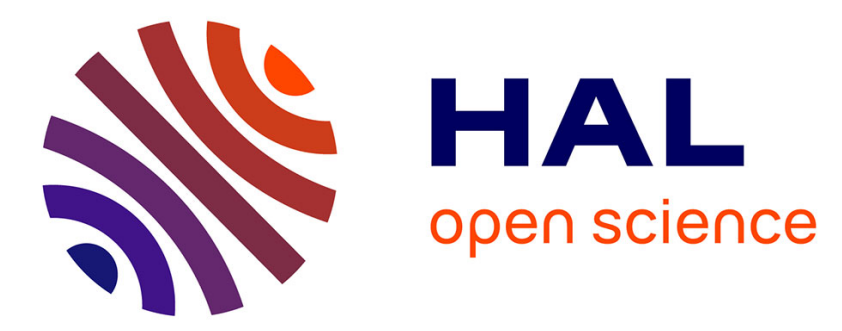

\title{
Role of CO2 in low to medium enthalpy geothermal systems in the Central Betic Cordillera (Spain)
}

C. Lix, P. Zuddas, X. Guichet, J. Benavente, J.A. Luque-Espinar, M. M.

Barbier

\section{- To cite this version:}

C. Lix, P. Zuddas, X. Guichet, J. Benavente, J.A. Luque-Espinar, et al.. Role of CO2 in low to medium enthalpy geothermal systems in the Central Betic Cordillera (Spain). Science of the Total Environment, 2020, 705, pp.135652. 10.1016/j.scitotenv.2019.135652 . hal-02447029

\section{HAL Id: hal-02447029 \\ https://hal-ifp.archives-ouvertes.fr/hal-02447029}

Submitted on 22 Apr 2020

HAL is a multi-disciplinary open access archive for the deposit and dissemination of scientific research documents, whether they are published or not. The documents may come from teaching and research institutions in France or abroad, or from public or private research centers.
L'archive ouverte pluridisciplinaire HAL, est destinée au dépôt et à la diffusion de documents scientifiques de niveau recherche, publiés ou non, émanant des établissements d'enseignement et de recherche français ou étrangers, des laboratoires publics ou privés. 
Role of $\mathrm{CO}_{2}$ in low to medium enthalpy geothermal systems in the Central Betic Cordillera (Spain)

C. Lix ${ }^{1,2 *}$, P. Zuddas ${ }^{2}$, X. Guichet ${ }^{1}$, J. Benavente ${ }^{3}$, J.A. Luque-Espinar ${ }^{4}$, and M. Barbier ${ }^{1}$

${ }^{1}$ IFP Energies Nouvelles, 1 et 4 avenue de Bois-Préau, 92852 Rueil-Malmaison, France

${ }^{2}$ Sorbonne Université, CNRS-INSU, Institut des Sciences de la Terre Paris, ISTeP UMR 7193, F-75000

Paris, Campus Pierre et Marie Curie - 4 place Jussieu 75005 Paris, France

${ }^{3}$ Departamento de Geodinámica e Instituto de Investigación del Agua, Universidad de Granada, Avenida de la Fuente Nueva S/N C.P. 18071- Granada, Spain

${ }^{4}$ Instituto Geológico y Minero de España, Urb. Alcázar del Genil, 4-Edif. Zulema, Bajo., 18006 - Granada, Spain

Corresponding author: Claire Lix 
1 Role of $\mathrm{CO}_{2}$ in low to medium enthalpy geothermal systems in the Central Betic Cordillera 2 (Spain)

3 Abstract

There is growing interest in geothermal energy, which is considered as an efficient energy

5 solution to mitigate rising atmospheric $\mathrm{CO}_{2}$. Besides known high enthalpy geothermal systems, increasing attention is paid to low temperature geothermal systems, as they are suitable for local use. Although geothermal production seems to be an environmentally advantageous renewable energy, it might result in significant $\mathrm{CO}_{2}$ emissions. In this study, we investigate the relationship between temperature, fugacity of $\mathrm{CO}_{2}\left(f \mathrm{CO}_{2}\right)$, and mineral buffers in the reservoir conditions, taking the low- to medium- enthalpy thermal waters in the Central Betic Cordillera as case study. Using geochemical modeling, three main groups of waters have been identified depending on temperature, buffering mineral assemblage, and $\mathrm{fCO}_{2}$ in their reservoir. A group of waters with a reservoir temperature ranging from 70 to $90^{\circ} \mathrm{C}$ and located in the intramountain sedimentary basins shows a $f \mathrm{CO}_{2}$ in depth ranging from $\sim 6 \times 10^{-2}$ and $6 \times 10^{-1}$. The reservoir chemistry of this water group seems to be mainly controlled by carbonates and evaporites displaying a $f \mathrm{CO}_{2}$ variation between depth and surface $\left(\triangle f \mathrm{CO}_{2}\right)$ of $10^{-1}$. Another intermediate group of waters, located in an active extension zone, displays lower temperature $\left(50-60^{\circ} \mathrm{C}\right)$ and $f \mathrm{CO}_{2}$ in the reservoir (from $10^{-3}$ to $10^{-2}$ ). Finally, the third group of waters, located on the metamorphic complexes contacts, show the highest estimated temperatures $\left(130-140^{\circ} \mathrm{C}\right)$ and $20 f \mathrm{CO}_{2}$ in the reservoir $\left(1\right.$ to $\left.10^{2}\right)$. The two latter groups suggest increasing buffering effect of alumino-silicates, in addition to carbonates and quartz. Therefore, we evidenced a strong relationship between temperature and $f \mathrm{CO}_{2}$ in the reservoir as well as the potential mineral buffers. We discussed the potential of geothermal systems as clean energy source based on the 24 estimation of the $\mathrm{CO}_{2}$ emissions generated by the investigated thermal systems for a practical case of household heating. 


\section{Introduction}

Geothermal energy has been widely developed across Europe and the World for the last 50 years, with main focus on the conventional high-temperature geothermal reservoirs. Nevertheless, low $\left(30^{\circ} \mathrm{C}\right.$ to $\left.100^{\circ} \mathrm{C}\right)$ to medium $\left(100-150^{\circ} \mathrm{C}\right)$ enthalpy geothermal systems have been recently subject to increasing interest (Blasco et al., 2017; Capecchiacci et al., 2015; Fusari et al., 2017) as they may be easily exploited for ground-source heat pump or greenhouses (Battistel et al., 2016). In the current context of global warming and energy transition, geothermal is generally considered to be an environmentally advantageous renewable source of energy. However, emissions of greenhouse gases, and especially $\mathrm{CO}_{2}$, might be generated by geothermal exploitation. Although $\mathrm{CO}_{2}$ release from geothermal electricity production has been shown to be significantly lower than from fossil fuel (Ármannsson, 2003; Hunt, 2001), the efficiency of this energy to mitigate rising atmospheric $\mathrm{CO}_{2}$ is a major concern for societal acceptance. Scientific research programs have been recently dedicated to the development of cost-effective non-carbon emitting geothermal energy (e.g., "Geothermal Emission Gas Control", Horizon 2020, European program). The studies on the $\mathrm{CO}_{2}$ emissions in geothermal systems are mainly dedicated to volcanic geothermal systems (e.g., Ármannsson, 2018; Chiodini et al., 1998; Harvey et al., 2017; Seward and Kerrick, 1996). However, the expansion of the geothermal sector leads to consider a broader range of geothermal resources resulting in possible large $\mathrm{CO}_{2}$ emissions, even in low- and medium- enthalpy geothermal systems.

The $\mathrm{CO}_{2}$ concentration in geothermal waters is strongly related to the geological setting, and more specifically the lithology, of the reservoir. The role of carbonates might be predominant in generation of $\mathrm{CO}_{2}$ as carbonate dissolution or thermal decomposition of carbonates might be major sources of $\mathrm{CO}_{2}$ in fluid whereas carbonate precipitation in the reservoir or in the ascent of the water might be a sink of geothermal $\mathrm{CO}_{2}$. The equilibrium relative to the carbonate minerals and the alumino-silicate minerals, often associated to the 
chemical water-rock interactions, is an important parameter to consider as it "buffers" the fluid chemical composition and the $\mathrm{CO}_{2}$ degassing. Therefore, understanding the relationship between the mineral buffer, the fugacity of $\mathrm{CO}_{2}\left(f \mathrm{CO}_{2}\right)$ (or its partial pressure of $\mathrm{CO}_{2}, \mathrm{pCO}_{2}$ ), and the temperature in the reservoir, is crucial to estimate the $\mathrm{CO}_{2}$ release in geothermal systems. These links between $f \mathrm{CO}_{2}$ and reservoir temperature have been subject to Chiodini and collaborators' investigations since the early 1990's, although they focused mainly on volcanic geothermal systems (e.g., Chiodini et al., 2007, 1998, 1995b)

The Central Betic Cordillera, in the South of Spain, has an interesting geothermal potential with abundant low to medium geothermal resources (Arrizabalaga et al., 2015; Sánchez Guzmán and García de la Noceda, 2010), major fault systems allowing a rapid ascent of the deep hot water (Cerón and López-Chicano, 2002), and moderate-intensity seismic activity. This region is characterized by several occurrences of thermal springs (water with temperature of more than $20^{\circ} \mathrm{C}$, according to the average air temperature of this area), known as baños, which have been used, for some of them, as thermal bath since the Roman times. They are mainly exploited for balneotherapy or spa nowadays. The thermal waters in the Central Betic Cordillera are also characterized by large variability in $f \mathrm{CO}_{2}$, and therefore in $\mathrm{pCO}_{2}$. Low $f \mathrm{CO}_{2}$ are observed in the sulfated waters (e.g., Baños Alhama de Granada) whereas large amount of $\mathrm{CO}_{2}$ degassing are known in few springs (e.g., Capuchina de Lanjaron) (Pérez del Villar, 2009). The thermal springs of Baños Alicun de la Torres have been studied as natural analogs for $\mathrm{CO}_{2}$ storage (Prado-Pérez and Pérez del Villar, 2011). Nevertheless, only old Spanish studies have considered globally the thermal waters in the Central Betic Cordillera (Benavente Herrera and Sanz de Galdeano, 1985; Cruz-Sanjulián et al., 1972; Cruz Sanjulián and Granda, 1979). Recent studies (Campos, 2006; López-Chicano et al., 2001a; Prado-Pérez and Pérez del Villar, 2011) characterized the geochemical and hydrogeological properties in specific individual thermal system. 
The aim of this study is to evaluate the suitability of the thermal waters for the geothermal exploitation in the Central Betic Cordillera with regard to $\mathrm{CO}_{2}$ emissions. Geochemical and isotopic indicators and thermodynamic calculations can be applied to get insights on the fluid geochemistry, temperature, and $f \mathrm{CO}_{2}$ of the reservoir using the measured physical-chemical characteristics at the surface. The present study attempts to assess the potential mineral assemblages buffering the waters in the reservoir and the variations of $f \mathrm{CO}_{2}$ at the regional scale.

\section{Geological setting}

The sampled thermal waters (springs and wells) are located in the central region of the Betic Cordillera with a greater concentration of points in the Granada Basin (

Figure 1). The Central Betic Cordillera is a complex structure, resulting from the convergence of the Iberian and African plates, which can be subdivided into: (1) the nonmetamorphic External Zone, (2) the metamorphic Internal Zones, (3) the Neogene basins. The External Zone is separated from the Internal Zone by a major shear zone called the Internal External Boundary Zone (IEBZ) (Sanz de Galdeano, 1990). The Granada Basin is one of the Neogene intramontainous basin in the Central Betic Cordillera, located at the junction between the Internal and External zones.

\section{$2.1 \quad$ Tectonic framework}

The Central Betic Cordillera is a tectonically active region structured by several crustal faults (Buforn et al., 2004; Sanz de Galdeano and Peláez, 2011). In the NE part of the Granada Basin, the IEBZ, mentioned above, becomes nearly coincident with the so-called CadizAlicante faults system (CAFS,

Figure 1) extending along $550 \mathrm{~km}$ across the Betic Cordillera. This fault system forms a 
101 corridor of dextral strike-slip faults generating crustal discontinuities of at least $7 \mathrm{~km}$ depth

102 (Sanz de Galdeano, 2008 and references therein). Besides, two main sets of normal faults affect 103 the basement and the sedimentary infilling of the Granada Basin: one set of E-W faults with 104 low angle dip $\left(<30^{\circ}\right)$ toward the south and the north; and a second one with NW-SE faults, 105 which dip westward, mainly located in the NE of the basin (Figure 1) (Galindo-Zaldívar et al., 106 2015; Rodríguez-Fernández and Sanz de Galdeano, 2006). The thermal waters are strongly 107 related to the faults in the Central Betic Cordillera as the thermal systems are convective 108 fracture-controlled systems (Benavente Herrera and Sanz de Galdeano, 1985; Cruz-Sanjulián et al., 1972).

\section{$2.2 \quad$ Lithostratigraphy}

The material of the Internal Zone corresponds to Paleozoic to Mesozoic metasediments differentiated into three stacked metamorphic complexes, from the top to the base, by different

114 metamorphic degree and structural position: (1) Maláguide, (2) Alpujárride, and (3) NevadoFilábride. The Alpujárride Complex, well represented in our study area, consists in a series of nappes of Paleozoic-Mesozoic HP/LT metasediments (Azañón et al., 1998; Azañón and

117 Crespo-Blanc, 2000). The base of the nappes consists of Paleozoic graphite mica schists, which

118 are overlain by Permo-Triassic metapelites with layers of meta-sandstones, dolomite, and

119 limestone. These meta-sediments are in turn overlain by middle-upper Triassic marbles with interbedded gypsum layers and Mesozoic pelagic marls forming the top of the nappes (Martín and Braga, 1987; Prado-Pérez and Pérez del Villar, 2011). The HP/LT Nevado-Filábride materials, outcropping in the Sierra Nevada and Sierra Alhamilla, comprise from the base to

123 the top: Paleozoic graphitic schists, Permo-Triassic mica schists associated with metapelites,

124 Triassic dolomite and marbles, and heterogeneous rocks with Jurassic metabasite inclusions 125 (Gomez-Pugnaire et Fernandez-Soler, 1987; Gómez-Pugnaire et al., 2000). 
The External Zone forms the northern part of the Granada Basin basement and crops out in

Sierra Elvira and Alicún de las Torres. It is mainly composed of Mesozoic sedimentary rocks, with Triassic evaporitic-bearing marls, dolomitic limestones, and interbedded marls (Braga et al., 2003; Sanz de Galdeano and Vera, 1992).

The sedimentary infilling of the Granada Basin ranges from the Miocene to the Quaternary and is composed, from bottom to top, of clayey conglomerates, calcareous sandstones, marls and silts, gypsum/anhydrite (and locally halite), lacustrine limestones, cemented breccias and alluviums (Braga et al., 2003; Corbí et al., 2012).

\subsection{Sample location}

The thermal waters are mainly situated close to major tectonic and geological structures. The sampling points can be gathered into three groups depending of the nature of the geological features:

- The thermal waters related to the metamorphic complexes: Baño Salado de Lanjaron and Capuchina de Lanjaron springs (BSL and CL) are located in the Sierra Nevada along the detachment between Nevado-Filábride and Alpujárride complexes. Baños Alhamilla spring (BAA) is situated further to the east in the Sierra Alhamilla along the same tectonic contact, where it is also close to the trace of an important strike-slip fault of near N30E direction.

- The thermal waters located in the evaporitic basins (Granada Basin and Guadix-Baza Basin): Baños Santa Fe (SF), Baños de la Malahá (BM), and Sondeo Romilla de la Nueva (SRN) are wells situated in the Granada Basin. Baños Alhama de Granada (BAG), Baños Nuevo Alhama de Granada (BNAG), and Sierra Elvira (SE) are springs located in the Granada Basin. SE is also located on the trace of an active fault, belonging to the NW to NNW directed fault system. Baños de Zujar (BZ) and Baños de Alicún de 

las Torres (AT) are springs located in the Guadix-Baza Basin, close to the above mentioned IEBZ and CAFS. The springs SE, BZ, and AT are linked by faults to small Subbetic carbonate outcrops.

- The thermal waters linked to the Baños Urquizar Chico (BUC) and Baños Urquizar Grande (BUG) are located within the Valle de Lecrin tectonic graben within the Alpujárride Complex along faults striking N30E, forming the western termination of the Sierra Nevada Massif.

\section{Material and methods}

\subsection{Water and dissolved gases sampling}

Thirteen thermal water samples were collected in the Granada Basin and in the Betic Cordillera, from nine springs and four wells. Two wells were artesian whereas the other water samples were pumped. All water samples were filtered with $0.45 \mu \mathrm{m}$ membrane filters and samples assigned to trace elements and $\mathrm{Al}$ analyses were filtered with $0.2 \mu \mathrm{m}$ membrane filters.

The water samples dedicated to cations, minor elements, and $\mathrm{Al}$ analyses were acidified using suprapure nitric acid $\left(\mathrm{HNO}_{3}\right)$.

Waters were collected by filling $142 \mathrm{~mL}$ Pyrex glass bottles to analyze chemical composition of dissolved gases (Capasso and Inguaggiato, 1998; Inguaggiato and Rizzo, 2004; Lix et al., 2018). The glass bottles were sealed under water with silicon/rubber septa to minimize atmospheric contamination (Capasso and Inguaggiato, 1998).

\subsection{Water analyses}

3.2.1 Physical-chemical properties

Physical-chemical parameters of the waters, including temperature, $\mathrm{pH}$, electrical 
conductivity (EC), and alkalinity were measured directly on the field. The combination $\mathrm{pH}$ electrode was calibrated with three buffer solutions at $\mathrm{pH} 4.0,7.0$ and $10.0\left(25^{\circ} \mathrm{C}\right)(\mathrm{CertiPUR} \AA$ Reference material) and the EC electrode with two potassium chloride standard solutions of $1.41 \mathrm{mS} / \mathrm{cm}$ and $12.8 \mathrm{mS} / \mathrm{cm}\left(25^{\circ} \mathrm{C}\right)($ CertiPUR $®$ Reference material). The uncertainties on the measurements of temperature, $\mathrm{pH}$, and $\mathrm{EC}$ were of $\pm 1^{\circ} \mathrm{C}, \pm 0.1$, and $\pm 0.01 \mathrm{mS} / \mathrm{cm}$ respectively. Alkalinity was determined by titration with an $0.01 \mathrm{M}$ or $0.1 \mathrm{M}$ hydrochloric acid solution depending on the encountered alkalinity range and by following the $\mathrm{pH}$ evolution with the $\mathrm{pH}$ meter. The equivalent volume was determined with the Gran's method (Gran, 1952) and the analytical error of the alkalinity measurements was of approximatively $\pm 5 \%$.

\subsubsection{Laboratory chemical analyses}

The major cations and anions $\left(\mathrm{Ca}^{2+}, \mathrm{Mg}^{2+}, \mathrm{K}^{+}, \mathrm{Na}^{+}, \mathrm{SO}_{4}{ }^{2-}\right.$, and $\left.\mathrm{Cl}^{-}\right)$were analyzed by ionic chromatography. The uncertainty on $\mathrm{Mg}^{2+}, \mathrm{K}^{+}, \mathrm{Na}^{+}, \mathrm{SO}_{4}{ }^{2-}$ determination is $\pm 5 \%$ whereas that on $\mathrm{Ca}^{2+}$ and $\mathrm{Cl}^{-}$is estimated to be $\pm 10 \%$. Minor and trace elements $(\mathrm{Ba}, \mathrm{Sr}, \mathrm{Al}, \mathrm{Fe})$ were analyzed by Inductively Coupled Plasma Optical Emission Spectrometry ICP-OES. The uncertainty on $\mathrm{Ba}$ and $\mathrm{Sr}$ determination is $\pm 10 \%$ whereas that on $\mathrm{Al}$ is estimated to $\pm 20 \%$.The silica concentrations were determined by a spectrophotometric method following the protocol from Centre d'Expertise en Analyse Environnementale du Québec, (2016), suitable for natural groundwater with Si concentration ranging from 0 to $20 \mathrm{mg} / \mathrm{l}$. The total ionic balance does not exceed $8 \%$ for all water samples.

\subsection{Gas analyses}

\subsubsection{Extraction and analyses of dissolved gases}

The extraction of the dissolved gases was carried out following the method described by Capasso and Inguaggiato (1998) and Inguaggiato and Rizzo (2004). A known volume of host 
gas was injected into the upside-down glass bottles while drawing out the equivalent water 201 volume through needles. After equilibration for 24 hours, a variable gas volume was extracted 202 for analyses by injecting Millipore water into the glass bottles.

203 Gas species $\left(\mathrm{O}_{2}, \mathrm{~N}_{2}, \mathrm{CH}_{4}, \mathrm{CO}_{2}\right.$ and $\left.\mathrm{He}\right)$ were analyzed by gas chromatography (Clarus 500, 204 Perkin Elmer instrument with Carboxen 1000 columns with a hot wire detector and a flame 205 ionization detector) using argon as carrier gas. The composition of dissolved gases, expressed 206 in cc. l $^{-1}$ STP (Standard Temperature and Pressure), was calculated taking into account the 207 volume of gas extracted, the volume of water sample, and the solubility of each gas species 208 (Bunsen coefficient in cc gas/l water STP). The composition of bubbling gases was expressed 209 in either \%vol or ppm vol. The accuracy to analyze dissolved gases following the method 210 described by Capasso and Inguaggiato (1998) is within 5.0\%.

3.4 $\quad \delta^{13} \mathrm{C}$ of the Total Dissolved Inorganic Carbon (TDIC)

Analyses of $\delta^{13} \mathrm{C}$ of Total Dissolved Inorganic Carbon (TDIC) were carried out with the Analytical Precision 2003 (AP2003) mass spectrometer using the method outlined by Capasso et al. (2005) based on chemical and physical stripping. The results were expressed in \%o vs. VPDB standard and with standard deviations of ${ }^{13} \mathrm{C} /{ }^{12} \mathrm{C}$ ratios of $\pm 0.2 \%$.

\subsection{Geochemical calculations and modeling}

In this study, the saturation index calculations and geothermometrical modeling were performed with the (version 3-0-6) PHREEQC software (Parkhurst et al., 2013), using the phreeqc thermodynamic database distributed with the code. 
A direct thermodynamic modeling of the multi-component system equilibrium has been 225 performed from the composition of the waters and the physical-chemical parameters. The saturation index of waters with respect to possible minerals $\left(\mathrm{SI}_{\mathrm{m}}\right)$ were calculated to test the equilibrium conditions or the departure from equilibrium of the system, following Equation 1:

$$
S I_{m}=\log \Omega_{m}=\log \frac{\prod^{i}\left(\gamma_{i}\left[c_{i}\right]\right)^{v_{i m}}}{K_{s}(P, T)_{m}}
$$

where $\left[\mathrm{c}_{\mathrm{i}}\right]$ and $\gamma_{i}$ are the concentration and the activity coefficient of the ion $\mathrm{i}, v_{\mathrm{im}}$ is the reaction coefficient for the ion $\mathrm{i}$ and the mineral $\mathrm{m}$, and $\mathrm{K}_{\mathrm{S}}(\mathrm{P}, \mathrm{T})_{\mathrm{m}}$ is the solubility constant of the mineral m dependent on temperature and pressure.

\subsubsection{Chemical geothermometers and geobarometers}

Chemical geothermometric techniques were used to estimate the theoretical reservoir temperature of the thermal waters. The application of the chemical geothermometers needs to satisfy the basic assumptions that the waters circulating at depth are in chemical equilibrium with the minerals of the host rocks (i.e., $\mathrm{SI}_{\mathrm{m}}$ close to 0 ) and that their elemental contents have not changed significantly during the water ascent to the surface (including precipitation or dissolution of secondary mineral phases or degassing). Numerous chemical geothermometers have been described in the literature, including silica, $\mathrm{Na} / \mathrm{K}, \mathrm{Na} / \mathrm{K} / \mathrm{Ca}, \mathrm{K}-\mathrm{Mg}$ (D'Amore et al., 2000 and references therein). The silica geothermometers are the most common in geochemical investigations of geothermal systems, widely used in different contexts around the world (Verma, 2000a). However, the validity of the silica geothermometers, and especially $\mathrm{SiO}_{2-}$ quartz geothermometers, have been questioned at low temperatures $\left(<100^{\circ} \mathrm{C}\right)($ Fournier, 1977 ; Rimstidt and Barnes, 1980; Verma, 2000a). At those temperatures, quartz precipitation rate is very slow and saturation is rarely achieved (Bjorlykke and Egeberg, 1993; Rimstidt and Barnes, 1980). Nevertheless, these geothermometers might provide consistent results even at low to 
medium temperatures (Blasco et al., 2018) and therefore they have been investigated in this 248 study. $\mathrm{SiO}_{2}$-quartz geothermometers from Fournier (1977), Fournier and Potter (1982), 249 Michard (1979) and Verma (2000b) and $\mathrm{SiO}_{2}$-chalcedony geothermometers from Arnórsson et 250 al. (1983) and Michard (1990) were applied for the studied thermal waters. Although cationic $251(\mathrm{Na} / \mathrm{K}, \mathrm{Na} / \mathrm{K} / \mathrm{Ca}, \mathrm{K}-\mathrm{Mg})$ geothermometers have been proven efficient in high temperature 252 systems $\left(>180^{\circ} \mathrm{C}\right)$, they are usually considered as unsuitable in low temperature systems due 253 to the different mineral assemblage governing the water chemistry and equilibrium (Blasco et 254 al., 2017; Chiodini et al., 1995a). Due to these limitations, the $\mathrm{Na} / \mathrm{K}, \mathrm{Na} / \mathrm{K} / \mathrm{Ca}$ and $\mathrm{K}-\mathrm{Mg}$ 255 geothermometers have not been applied in this study. The Ca-Mg geothermometer, developed 256 in the first place by Marini et al. (1986) and revised by Chiodini et al. (1995a), is more 257 appropriate for low temperature carbonate-evaporitic system and was therefore used here. This 258 geothermometer assumes equilibrium of the waters with calcite, dolomite and anhydrite in the reservoir, which is a reasonable assumption in the investigated area where these minerals are extensively present.

In order to get an estimation of the fugacity of $\mathrm{CO}_{2}\left(f \mathrm{CO}_{2}\right)$ at depth, the geobarometrical 262 relationship based on the $\left(\mathrm{HCO}_{3}^{-}\right)^{2} / \mathrm{SO}_{4}{ }^{2-}$ ratio, $f \mathrm{CO}_{2}$, and temperature (Chiodini et al., 1995a) 263 was applied using the following equation:

$$
\log \frac{\left(\mathrm{HCO}_{3}{ }^{-}\right)^{2}}{\mathrm{SO}_{4}{ }^{2-}}=-4.807+0.9871 \log p \mathrm{CO}_{2}+\frac{794.8}{T}-0.1655 \log \Sigma_{e q}
$$

264 where $\sum$ eq is the sum of equivalents in the waters.

\subsubsection{Geothermometrical modeling}

Another approach to estimate the reservoir temperature consists of simulating the variation of the saturation states with respect to a group of selected minerals, potentially present in the reservoir, to find the temperature at which the saturation indices simultaneously reach equilibrium (Blasco et al., 2018). This method is based on the same assumption as the classical 
chemical geothermometers: the thermal waters are in equilibrium with the mineral phases under reservoir conditions. Hence, the most realistic reservoir temperature corresponds to the temperature at which a group of minerals is at equilibrium (Asta et al., 2012; D'Amore et al., 1987; Tole et al., 1993).

Saturation indices were calculated in the temperature interval between the field temperature and $150^{\circ} \mathrm{C}$ for the following minerals: quartz, chalcedony, anhydrite, dolomite, calcite, Camontmorillonite, laumontite, Mg-chlorite, albite, anorthite, K-feldspar, and kaolinite. Due to the imprecision of the thermodynamic databases, the error on the SI at which the equilibrium is reached is considered to be SI $=0 \pm 0.25$ (D'Amore et al., 1987). This geothermometrical modeling approach estimates the reservoir temperature within an uncertainty of $\pm 10^{\circ} \mathrm{C}$ (Tole et al., 1993).

An additional set of geothermometrical simulations has been performed at the end of the study including addition of $\mathrm{CO}_{2}$ to the initial solution to test the hypothesis of $\mathrm{CO}_{2}$ degassing in an open system.

3.5.4 Hydrogeochemical modeling between surface and depth conditions in closed system

In order to assess the geochemistry of the waters at reservoir conditions and the variation of the $f \mathrm{CO}_{2}$ between the reservoir and the surface, we carried out hydrogeochemical simulations in closed systems. In sedimentary environments, the $\mathrm{pH}$ and $f \mathrm{CO}_{2}$ of the waters are highly dependent on the interaction with carbonate minerals. Dolomite is particularly important in the Central Betic Cordillera where large amount are present. $\mathrm{CO}_{2}$ generation might occurs during dolomite precipitation as shown by the following reaction:

$$
\mathrm{Ca}^{2+}+\mathrm{Mg}^{2+}+4 \mathrm{HCO}_{3}^{-} \leftrightarrow \mathrm{CaMg}\left(\mathrm{CO}_{3}\right)_{2(s)}+2 \mathrm{CO}_{2(g)}+2 \mathrm{H}_{2} \mathrm{O}
$$

The $f \mathrm{CO}_{2}$ in the system might also be controlled by reactions involving alumino-silicates 
and carbonates such as the conversion of kaolinite to Mg-chlorite proposed by CoudrainRibstein et al. (1998) and Hutcheon et al. (1993):

5 dolomite + kaolinite + quartz $+2 \mathrm{H}_{2} \mathrm{O} \leftrightarrow 5 \mathrm{CO}_{2}+5$ calcite $+\mathrm{Mg}$-chlorite

The modeling workflow was run with the PHREEQC code and includes the following three

301

302

303

304

305 steps:

(1) Saturation calculations were carried out at the outlet temperature $\left(\mathrm{T}_{\text {out }}\right)$ and atmospheric pressure $\left(\mathrm{P}_{\text {out }}\right)$,

(2) An increase in temperature was simulated up to the temperature of the quartz geothermometer $\left(\mathrm{T}_{\mathrm{qz}}\right)$ and the corresponding hydrostatic pressure of the reservoir $\left(\mathrm{P}_{\text {hydro }}\right)$ using a geothermal gradient of $30^{\circ} \mathrm{C} / \mathrm{km}$,

(3) Waters were equilibrated with a set of minerals at $\mathrm{T}_{\mathrm{qz}}$ and $\mathrm{P}_{\mathrm{hydro}}$, to test two different hypotheses:

- Equilibrium with dolomite using $\mathrm{CO}_{2(\mathrm{~g})}$ as an alternative phase to reach the equilibrium,

- Equilibrium with carbonates and alumino-silicates using calcite, dolomite, kaolinite, quartz, Mg-chlorite as mineral assemblage. These minerals are allowed to dissolve or precipitate to reach equilibrium.

The concentrations of chemical species, $\mathrm{pH}, \mathrm{CO}_{2}$ fugacity, and SI of minerals were computed during each step of modeling. By comparing the results of the geochemical modeling (Step 3) with the initial surface geochemical characteristics (Step 1), we evaluate the possible mineral assemblages in equilibrium at reservoir conditions.

These geochemical simulations rely on the assumption that the difference in the quartz saturation index ( $\left.\mathrm{SI}_{\text {quartz }}\right)$ during each step of the modeling does not lead to significant change in temperature. Even if $\mathrm{SI}_{\text {quartz }}$ varies between -0.13 and 1.27 , the $\mathrm{H}_{4} \mathrm{SiO}_{4}$ concentration remains 
quite constant for all the thermal waters resulting in a change in apparent temperature $(\delta \mathrm{T})$ lower than $5^{\circ} \mathrm{C}$.

\section{Results}

\subsection{Chemical characteristics of the waters}

The investigated thermal waters have outlet temperature ranging from 20 to $50^{\circ} \mathrm{C}$, corresponding to low to medium enthalpy waters, and $\mathrm{pH}$ values spanning between 5.8 and 7.6

(Table 1). The conductivity of the studied waters shows a large range of values, from 1 to 34 $\mathrm{mS} / \mathrm{cm}$, corresponding to total dissolved solids (TDS) values from 0.67 to $18.17 \mathrm{~g} . \mathrm{L}^{-1}$.

The thermal waters show a large variability in their chemical composition and a relationship can be evidenced between the water-types and their location relative to the geological structures in the Central Betic Cordillera (Figure 2).

The waters located in the graben formed in the Alpujárride Complex and close to the SENW faults have a chemical composition of $\mathrm{Ca}^{2+}-\mathrm{Mg}^{2+}-\mathrm{SO}_{4}{ }^{2-}-\mathrm{HCO}_{3}{ }^{-}$type, displaying interaction with both carbonates and sulfates.

The waters in the evaporitic basins are mainly $\mathrm{Ca}^{2+}-\mathrm{Mg}^{2+}-\mathrm{SO}_{4}{ }^{2-}$ water-type resulting from clear interaction with evaporitic material and especially calcium sulfate. The samples BAG and BNAG have a higher $\mathrm{HCO}_{3}{ }^{-}$content, with a composition close to the samples from the graben in the Alpujárride Complex. The composition of the BZ water also differs from the others with a $\mathrm{Ca}^{2+}-\mathrm{Na}^{+}-\mathrm{K}^{+}-\mathrm{SO}_{4}{ }^{2-}-\mathrm{Cl}^{-}$water-type, showing significant interaction with evaporitic and detrital material.

342 The thermal waters located at contacts between metamorphic complexes display larger 343 dispersion in their chemical composition. The samples BSL and CL are $\mathrm{Na}^{+}-\mathrm{Cl}^{-}$type whereas BAA is $\mathrm{Na}^{+}-\mathrm{Cl}^{-}-\mathrm{HCO}_{3}{ }^{-}$type. 


\subsection{Saturation indices}

The results of the saturation indices calculations at the outlet temperature are shown in

348 Table 2. The waters are mainly close to equilibrium or slightly oversaturated with respect to 349 calcite and dolomite whereas they are undersaturated with respect to gypsum, anhydrite, and halite. However, the thermal waters of AT and BSL display slight undersaturation to undersaturation with respect to the carbonate minerals (calcite and dolomite). Waters are oversaturated with respect to quartz and close to equilibrium with respect to chalcedony.

353 Concerning the saturation indices with respect to alumino-silicates, the waters are oversaturated with respect to kaolinite and Ca-montmorillonite whereas they display large range of saturation with respect to K-feldspar and albite, spanning from undersaturated to highly oversaturated, independently of the relationship with the tectonic structures. The saturation indices of the waters with respect to the considered minerals are $\mathrm{pH}$-dependent and therefore dependent of 358 possible $\mathrm{CO}_{2}$ degassing of the thermal waters.

\section{$4.3 \quad \mathrm{CO}_{2}$}

Dissolved $\mathrm{CO}_{2}$ concentrations range from 9.51 to $597.5 \mathrm{cc} / \mathrm{L}$, corresponding to $\mathrm{fCO}_{2}$ spanning from 0.02 to 0.78 , i.e $\mathrm{pCO}_{2}$ from 0.02 to 0.78 atm (Table 3). The water samples characterized by higher amounts of dissolved $\mathrm{CO}_{2}$ display lower $\mathrm{pH}$ values, suggesting that $\mathrm{CO}_{2}$ is the main species responsible of water acidity. The high- $\mathrm{CO}_{2}$ springs of CL, BAA and BUG are also characterized by bubbling gases with similar composition as the dissolved gases 365 (Lix et al., 2018).

The $f \mathrm{CO}_{2}$ values obtained from the speciation-solubility calculations at the outlet temperature range from 0.006 to 1.02 (Table 2). The total dissolved inorganic carbon content

368 of the thermal waters and its isotopic composition $\left(\delta^{13} \mathrm{C}_{\text {TDIC }}\right)$, listed in Table 3 , range from 2.7 x $10^{-3}$ to $6.3 \times 10^{-2}$ mol.L $L^{-1}$ and from -9.04 to $-1.54 \%$ vs. V-PDB respectively. 
degradation of organic matter in the soil (of the recharge area), (2) carbonate dissolution, (3) degassing of mantle-derived $\mathrm{CO}_{2}$. Biological degradation processes in soils usually results in $\delta^{13} \mathrm{C}$ values ranging from $-23 \%$ and $-9 \%$ (Clark and Fritz, 1997), which is not well representative of the studied samples. Therefore, the $\delta^{13} \mathrm{C}_{\mathrm{TDIC}}$ values indicate mainly inorganic origin of $\mathrm{CO}_{2}$ although possible mixing with organic carbon sources cannot be rouled out.

376 Discriminating the carbon source between carbonate dissolution and mantle-derived $\mathrm{CO}_{2}$ might 377 be more complex as their $\delta^{13}$ Cvalues overlap, He isotopic composition of dissolved and bubbling gases in these thermal waters show however a dominant crustal component (Lix et al., 2018). Purely inorganic origin of $\mathrm{CO}_{2}$ has been considered in these thermodynamical 380 calculations, given the results of $\delta^{13} \mathrm{C}$ of the TDIC.

\subsection{Reservoir temperature and pressure}

\subsubsection{Chemical geothermometers and geobarometers}

The temperatures provided by the silica and $\mathrm{Ca}-\mathrm{Mg}$ geothermometers are compiled in Table

4. The reservoir temperatures estimated with the different $\mathrm{SiO}_{2}$-quartz geothermometers range from 42 to $146^{\circ} \mathrm{C}$ corresponding to a mean spanning between 51 and $143^{\circ} \mathrm{C}$ with a relative standard deviation lower than $6^{\circ} \mathrm{C}$. The $\mathrm{SiO}_{2}$-chalcedony geothermometers yields lower temperatures ranging from 20 to $115^{\circ} \mathrm{C}$. The $\mathrm{SiO}_{2}$-quartz are more reliable than the $\mathrm{SiO}_{2}-$

389 chalcedony geothermometers since quartz might be the phase controlling the dissolved silica in 390 the thermal waters in the Betic Cordillera. Indeed, quartz occurrences and mineralizations have 391 been described in the Internal Zones of the Betic Cordillera as well as in the Neogene basins 392 whereas chalcedony have not been described in mineral assemblages. Although the kinetics of 393 quartz reaction is very slow below $100^{\circ} \mathrm{C}$ (Rimstidt and Barnes, 1980), the mineral equilibrium 394 approach developed in this study might support the temperatures obtained from quartz 395 geothermometers. 
The thermal waters located in the evaporitic basins (Granada and Guadix-Baza Basins) show estimated reservoir temperature from $\mathrm{SiO}_{2}$-quartz ranging from 74 to $95^{\circ} \mathrm{C}$. Assuming a thermal gradient of $30^{\circ} \mathrm{C} / \mathrm{km}$, which can be expected in the studied area (Fernàndez et al., 1998), these temperatures would correspond to depths and hydrostatic pressures varying from 2.5 to $3.2 \mathrm{~km}$ and from 250 to 320 atm respectively. The thermal waters BUC and BUG, located close to the SE-NW faults, show the lowest estimated reservoir temperature, ranging from 51 to $58^{\circ} \mathrm{C}$ and corresponding to hydrostatic pressure spanning between 170 and 200 atm respectively. The thermal waters located at the contacts between metamorphic complexes (BAA, CL, and BSL) show the highest estimated reservoir temperatures ranging from 126 and $142^{\circ} \mathrm{C}$, corresponding to depths of $4-4.5 \mathrm{~km}$ and a hydrostatic pressures of 400 to $450 \mathrm{~atm}$.

The Ca-Mg geothermometer provides temperatures ranging mainly between 71 and $91{ }^{\circ} \mathrm{C}$ with little variation between the different thermal waters (Table 4). The obtained temperatures are in good agreement with those of $\mathrm{SiO}_{2}$-quartz geothermometers for the waters located in the evaporitic Granada Basin. However, the $\mathrm{Ca}-\mathrm{Mg}$ geothermometer give similar reservoir temperatures regardless of the geological context of the studied thermal waters, due to low variations in their $\mathrm{Ca} / \mathrm{Mg}$ ratios, ranging mainly from 1.5 to 2.4. Therefore, it seems that this geothermometer might not be suitable for all investigated thermal waters in the central Betic Cordillera.

414 The results of the geobarometrical method based on the $\left(\mathrm{HCO}_{3}{ }^{-}\right)^{2} / \mathrm{SO}_{4}{ }^{2-}$ ratio $($ Chiodini et al., 1995a) give values of fugacity of $\mathrm{CO}_{2}\left(f \mathrm{CO}_{2}\right)$ in depth ranging from 0.04 to approximatively 23. The high values (> 5) are obtained for the thermal waters located on the contact of metamorphic complexes (CL, BSL, and BAA).

\subsubsection{Geothermometrical modeling}

The first results of the geothermometrical modeling including all mineral phases (quartz, 
chalcedony, anhydrite, dolomite, calcite, Ca-montmorillonite, laumontite, Mg-chlorite, and kaolinite) do not reach a common equilibrium temperature (Figures 3 and 4).

Although we can expect the carbonates as part of the buffering mineral assemblage in depth due to their ubiquity in the sedimentary basin and in the Central Betic Cordillera, they cannot reach equilibrium in the reservoir conditions. As shown in Figures 3 and 4, the waters are close to equilibrium or oversaturated with respect to calcite and dolomite in the outlet conditions and these minerals have retrograde solubility. The apparent oversaturation in the outlet conditions might result from $\mathrm{CO}_{2}$ outgassing process and a corresponding increase in $\mathrm{pH}$ during the ascent of the waters to the surface.

\subsubsection{Hydrogeochemical modeling}

The results of the simulations show that, globally, $\mathrm{fCO}_{2}$ in the outlet conditions varies between $6 \times 10^{-3}$ and 1, i.e. $\mathrm{pCO}_{2}$ between $\sim 6 \times 10^{-3}$ and $1 \mathrm{~atm}$. The $f \mathrm{CO}_{2}$ obtained in the third step of the simulation after equilibration with dolomite show values ranging from $\sim 2 \times 10^{-2}$ and 40 (Figure 5), whereas the values of $f \mathrm{CO}_{2}$ after equilibration with alumino-silicates and carbonates vary between $5.4 \times 10^{-3}$ and $1.8 \times 10^{2}$ (Figure 6). The logarithmic relationship between $\mathrm{fCO}_{2}$ and temperature for the waters equilibrated with the both carbonates and alumino-silicates might reflect strong control by the equilibrium mineral assemblage on the chemical water composition and $\mathrm{CO}_{2}$ content.

The geochemical modeling allows discriminating the three groups of waters, already distinguished by geology, regarding the $f \mathrm{CO}_{2}$ in the reservoir conditions:

- Group of waters located in the evaporitic basins

The results of the simulations in the evaporitic Granada Basin give a $\mathrm{pH}$ of the waters in equilibrium with dolomite in the reservoir conditions $\left(74<\mathrm{T}<95^{\circ} \mathrm{C}\right.$ and $250<\mathrm{P}_{\text {hydro }}<320$ 
atm) ranging from 6.5 to 6.8 and an estimated $f \mathrm{CO}_{2}$ spanning between $9 \times 10^{-2}$ and $1.6 \times 10^{-1}$

(Figure 5). The simulations taking into consideration carbonates and alumino-silicates give similar ranges of $\mathrm{pH}$ (from 6.5 to 6.7 ) and $\mathrm{fCO}_{2}$ (from $6 \times 10^{-2}$ to $2 \times 10^{-1}$ ) to those obtained with dolomite equilibrium for the water points located in the Granada basin (Figure 6). However, the two samples BNAG and BZ show slightly higher $f \mathrm{CO}_{2}$ ranging from $3 \times 10^{-1}$ and $6 \times 10^{-1}$. The thermal water of Alicun de las Torres (AT), showing a lower reservoir temperature similar to BUC and BUG samples, have an estimated low $f \mathrm{CO}_{2}$ at depth for both simulations ranging from $1 \times 10^{-2}$ to $3 \times 10^{-2}$ (Figure 5 and 6 ). The variation in $f \mathrm{CO}_{2}$ between the steps 1 and 3 of the simulation, $\Delta f \mathrm{CO}_{2}$, estimated for this group of thermal waters ranges from $3 \times 10^{-}$

2 to $6 \times 10^{-1}$ (Figure 7). This corresponds to a difference in calculated $\mathrm{CO}_{2}$ concentration between the steps 1 and 3 of the simulations ranging from $\sim 1$ to $5 \mathrm{mmol} / \mathrm{L}$.

- Group of waters in the graben in the Alpujárride complex

The results of the equilibrium simulations with dolomite in the reservoir conditions $(51<$ $\mathrm{T}<58^{\circ} \mathrm{C}$ and $170<\mathrm{P}_{\text {hydro }}<200 \mathrm{~atm}$ ) for the waters located in the graben into the Alpujárride

Complex give a $\mathrm{pH}$ of the waters of approximatively 6.8 and an estimated $f \mathrm{CO}_{2}$ of $6 \times 10^{-2}$ (Figure 5). The simulation of these waters in equilibrium with both carbonates and aluminosilicates (calcite, dolomite, quartz, kaolinite, and Mg-chlorite) give higher values of $\mathrm{pH}$ ranging from 7.3 to 7.4 and lower values of $f \mathrm{CO}_{2}$ spanning between $5 \times 10^{-3}$ and $9 \times 10^{-3}$ (Figure 6). The estimated variation in $f \mathrm{CO}_{2}$ between the depth and the surface, $\Delta f \mathrm{CO}_{2}$, ranges from $\sim 0$ to $6 \mathrm{x}$ $10^{-2}$ (Figure 7), corresponding to maximum $1 \mathrm{mmol} / \mathrm{L}$ of $\mathrm{CO}_{2}$.

- Group of waters located at contact with metamorphic complexes Both geochemical simulations show high $f \mathrm{CO}_{2}$ values $\left(>7 \times 10^{-1}\right)$ and low $\mathrm{pH}$ (ranging from 5.1 to 6.7$)$ at reservoir conditions $\left(126<\mathrm{T}<142^{\circ} \mathrm{C}\right.$ and $\left.400<\mathrm{P}_{\text {hydro }}<450 \mathrm{~atm}\right)$ for the thermal waters located at the contact with the metamorphic complexes. The estimated $f \mathrm{CO}_{2}$ at 
depth is lower considering the equilibrium with dolomite only (ranging from $6 \times 10^{-1}$ to 6 ) than considering the equilibrium with the carbonate and alumino-silicate assemblage (ranging from 25 to 180) (Figures 5 and 6). The estimated $\Delta f \mathrm{CO}_{2}$ for this group of thermal waters spans from $6 \times 10^{-1}$ to $1.8 \times 10^{2}$ (Figure 7), corresponding to $20 \mathrm{mmol} / \mathrm{L}$ to $0.85 \mathrm{~mol} / \mathrm{L}$ of $\mathrm{CO}_{2}$.

\subsubsection{Geothermometrical modeling with $\mathrm{CO}_{2}$ degassing (open system)}

- Group of waters located in the evaporitic basins

The geothermometrical simulations with the lowest estimation of $\mathrm{CO}_{2}$ addition deduced from the hydrogeochemical modeling, $1 \mathrm{mmol} / \mathrm{L}$, result in a common reservoir temperature of 75 to $90^{\circ} \mathrm{C}$ for the waters of the evaporitic basins (Figure 8). Waters are at potential equilibrium with the following mineral buffer: carbonates (calcite and dolomite), anhydrite, quartz, and possibly Mg-chlorite or $\mathrm{Ca}$ alumino-silicate (laumontite or a Ca-montmorillonite). These results show that low amounts of $\mathrm{CO}_{2}$ degassing $(\sim 1 \mathrm{mmol} / \mathrm{L})$ are necessary in an open system to reach the equilibrium with dolomite and alumino-silicates. Evaporites are also part of the buffer mineral assemblage in this sedimentary environment.

- Group of waters in the graben in the Alpujárride Complex

The geothermometrical simulations in an open system with addition of $0.5 \mathrm{mmol} / \mathrm{L} \mathrm{CO}_{2}$ show estimated reservoir temperatures ranging from 50 to $60^{\circ} \mathrm{C}$ for the waters located in the graben in the Alpujárride Complex (Figure 9) with the following mineral buffer: carbonates (calcite and dolomite), quartz, and Ca alumino-silicate (Ca-montmorillonite). Higher amounts of added $\mathrm{CO}_{2}$ do not lead to a common equilibrium of mineral phases at a specific temperature.

- Group of waters located at contact with metamorphic complexes Modeling of $\mathrm{CO}_{2}$ degassing in an open system with geothermometrical simulations shows that $7 \mathrm{mmol} / \mathrm{L}$ to $1 \mathrm{~mol} / \mathrm{L}$ of added $\mathrm{CO}_{2}$ are necessary for the waters to be at equilibrium at 
temperature ranging from 120 and $140^{\circ} \mathrm{C}$ with the following mineral assemblage: quartz and dolomite, and sometimes Mg-chlorite and laumontite (Figure 10).

\section{Discussion}

The thermal waters in the Central Betic Cordillera are characterized by large heterogeneity in their geochemistry in the outlet conditions and in their geothermal characteristics. The three groups of waters, which were defined based on water composition and geology at the thermal water locations, can be also distinguished by the temperature and $f \mathrm{CO}_{2}$ in the reservoir. The groups of thermal waters have distinct reservoir temperatures, estimated with the $\mathrm{SiO} 2$-quartz geothermometer, ranging from low-enthalpy $\left(\sim 55^{\circ} \mathrm{C}\right)$ to medium-enthalpy $\left(\sim 140^{\circ} \mathrm{C}\right)$ geothermal systems. Using the results of the geochemical and geothermometrical modeling we discuss in this section the mineralogical buffers and chemical properties of the reservoirs and

511 the variations in $f \mathrm{CO}_{2}$ between depth and the surface $\left(\triangle f \mathrm{CO}_{2}\right)$ in both closed and open system 512 for the three groups of waters. For all groups the assessed $\triangle f \mathrm{CO}_{2}$ indicates $\mathrm{CO}_{2}$ degassing during 513 the ascent of the water to the surface. The equilibrium with respect to mineral phases in the 514 reservoir conditions seems to have a strong control on $\mathrm{CO}_{2}$ release (Figure 7).

515 The group of thermal waters located in the sedimentary basins (Granada and Guadix-Baza 516 Basins), whose reservoir temperatures range from 74 to $95^{\circ} \mathrm{C}$, seem to be buffered at depth by 517 mainly carbonates, evaporites, quartz and a few alumino-silicates. The fact that there is a good 518 agreement in $\Delta f \mathrm{CO}_{2}$ with both dolomite buffer and carbonate/alumino-silicate buffer shows that 519 carbonates are the predominant mineral buffer in this environment. The values of $f \mathrm{CO}_{2}$ resulting 520 from geochemical simulations at depth are in quite good agreement with those estimated by the 521 geobarometer from Chiodini et al. (1995a), ranging from 0.04 to 0.16 . This geobarometer, 
specifically established for low- to medium- geothermal systems hosted in carbonates and evaporites, is certainly an efficient tool to estimate the reservoir $f \mathrm{CO}_{2}$ in this sedimentary context (similar range of temperature and $f \mathrm{CO}_{2}$ ).

The presence of evaporites needs to be considered for the geothermal systems in sedimentary environment as it might enhance $\mathrm{CO}_{2}$ release through a dedolomitization process. Prado-Pérez and Pérez del Villar (2011) showed that the thermal water AT may result from dedolomitization at depth followed by $\mathrm{CO}_{2}$ degassing. Dedolomitization, which is a process described in other natural systems (Auqué et al., 2009; López-Chicano et al., 2001b), corresponds to dolomite dissolution and calcite precipitation caused by the dissolution of gypsum and/or anhydrite. $\mathrm{CO}_{2}$ loss, before or after outlet of the thermal waters, might occur as evidenced by the presence of fossil and present-day massive thermogenic travertine deposits (Prado-Pérez and Pérez del Villar, 2011) in the Alicun de las Torres site. This process of dedolomitization is most probably occurring in other geothermal systems in the evaporitic Granada and Guadix-Baza basins.

For the thermal waters located in the graben in the Alpujárride Complex, which show the lowest estimated reservoir temperature, the buffer minerals are carbonates, quartz, and $\mathrm{Ca}$ alumino-silicate (Ca-montmorillonite). $\Delta f \mathrm{CO}_{2}$ is higher considering the dolomite buffer than considering the carbonate/alumino-silicate buffer. The difference in $f \mathrm{CO}_{2}$ simulated with the two types of mineral buffers (dolomite only and the carbonate/alumino-silicate association) for the thermal waters in the graben might be the signature of the basement, whereas the similar $f \mathrm{CO}_{2}$ estimated for the waters in the sedimentary basin would be the signature of the sedimentary pile. Moreover, the values of $f \mathrm{CO}_{2}$ for both simulations at depth are lower than those estimated by the geobarometer from Chiodini et al. (1995a) of 0.54 and 0.66 for BUC and BUG samples respectively.

On the other hand, for the group of waters located at contact with the metamorphic 
complexes, which displays the highest estimated reservoir temperature $\left(130-140^{\circ} \mathrm{C}\right)$, the

548 mineral buffer assemblage at depth is more difficult to assess due to the large $\mathrm{CO}_{2}$ degassing.

549 Indeed, these waters show the highest measured dissolved $\mathrm{CO}_{2}$ concentrations $\left(>39 \mathrm{~cm}^{3} / \mathrm{L}\right)$

550 distinguishing them from the other thermal springs in the Central Betic Cordillera. They are at

551 equilibrium with quartz and dolomite, and close to equilibrium with $\mathrm{Mg}$-chlorite and laumontite

552 in the reservoir conditions. The $\triangle f \mathrm{CO}_{2}$ is lower with the dolomite buffer than with the carbonate 553 and alumino-silicate buffer (Figure 7).

554 The results of the simulations show that $\mathrm{CO}_{2}$ degassing is lower in open system than in 555 closed system, highlighting the importance to evaluate the efficiency of the system to rapidly 556 ascend water from depth to the surface. Calcite precipitation might result from the $\mathrm{CO}_{2}$ 557 degassing process due to $\mathrm{pH}$ increase and kinetic constrains compared to dolomite precipitation. 558 The amount of precipitated calcite can be evaluated during a given time range using the amount 559 of $\mathrm{CO}_{2}$ loss during the ascent of the water and the estimated flow rate of the springs found in 560 literature and checked in the field (ranging from 0.2 to $100 \mathrm{~L} / \mathrm{s}$ ). Assuming a time range 561 comprised between 1,000 and $100,000 \mathrm{yr}$, the amount of calcite precipitated is estimated to 562 range from $\sim 10^{2}$ to $10^{6} \mathrm{~m}^{3}$ for the waters in the basins or their borders. This estimation is in 563 good agreement with the volume of travertines that can be deduced from the study of Martín564 Algarra et al. (2003) in the northeastern part of the Granada Basin (from $10^{4}$ to $10^{5} \mathrm{~m}^{3}$ for the 565 last 200,000 yr).

\subsection{Relationship between $f \mathrm{CO}_{2}$ and temperature}

Using thermodynamic calculations (hydrogeochemical and geothermometrical 569 simulations), we show the key role of the reservoir temperature and the buffer mineral 570 assemblage on the estimation of $f \mathrm{CO}_{2}$ and therefore $\mathrm{pCO}_{2}$. A recent study on the geochemical 571 characterization of geothermal systems pointed out that the $\mathrm{CO}_{2}$ trapping mechanism is mainly 
controlled by reservoir temperature (Elidemir and Güleç, 2018). In our studied area, we found increasing reservoir $f \mathrm{CO}_{2}$ with increasing reservoir temperature (Figure 7). The thermal waters with intermediate reservoir temperature $\left(70\right.$ to $\left.90^{\circ} \mathrm{C}\right)$ show the lowest uncertainty on the variation of $f \mathrm{CO}_{2}$ between depth and the surface $\left(\Delta f \mathrm{CO}_{2}\right)$ with the two mineral buffers (dolomite only and assemblage of carbonates and alumino-silicates). Higher uncertainty on $\Delta f \mathrm{CO}_{2}$ is 577 observed for the thermal springs with the higher reservoir temperature $\left(120-140^{\circ} \mathrm{C}\right)$ : carbonates 578 and alumino-silicates buffer predicts higher $\Delta f \mathrm{CO}_{2}$ than dolomite as mineral buffer. The 579 thermal waters with the lowest reservoir temperature also show a large uncertainty in $\Delta f \mathrm{CO}_{2}$ 580 but higher $\Delta f \mathrm{CO}_{2}$ is assessed considering dolomite equilibrium in the reservoir rather than 581 equilibrium with carbonates and alumino-silicates. The results of these highly-simplified 582 mineralogical systems suggest that dolomite tends to equilibrate at low temperature whereas 583 more silicates might be involved at high temperature leading respectively to higher uncertainty in $f \mathrm{CO}_{2}$. The difference in $\Delta f \mathrm{CO}_{2}$ between low and high temperature with respect to the considered mineral buffers might also be interpreted by the large uncertainty in thermodynamic data at the system temperature conditions.

5.3 Implications for sustainability of geothermal energy in the Central Betic Cordillera

In order to estimate the environmental impact associated with the $\mathrm{CO}_{2}$ degassing of the 591 investigated thermal waters, the $\mathrm{CO}_{2}$ emissions generated by these thermal systems were 592 estimated for potential household heating purpose and were compared to those produced by a 593 natural gas heating system. The average household energetic consumption (Q) for heating 594 system of a $100 \mathrm{~m}^{2}$ house in Western Europe is $11,600 \mathrm{kWh} / \mathrm{yr}$, equivalent to $4.18 \times 10^{10} \mathrm{~J} / \mathrm{yr}$ 595 (Lapillonne et al., 2014).

596 Using this average household energetic consumption, we can estimate the amount of $\mathrm{CO}_{2}$ 
$597\left(\mathrm{nCO}_{2}\right)$ that would be emitted from a natural gas furnace used to heat a $100 \mathrm{~m}^{2}$ house (Equation $598 \quad 3)$.

$$
\left(n_{\mathrm{CO}_{2}}\right)_{\text {emitted }}=\left(n_{\mathrm{CH}_{4}}\right)_{\text {consumed }}=\frac{Q}{\mathrm{HHV}}
$$

599

600

601

602

603

604

605

606 following equation:

$$
n_{\text {water }}=\frac{Q}{C p_{\text {water }} * \Delta T}
$$

607 where $\mathrm{Q}$ is the average value of household energetic consumption, $\mathrm{Cp}_{\text {water }}$ is the isobaric heat 608 capacity of water and $\Delta \mathrm{T}$ is the temperature range of the internal heating cycle $\left(20^{\circ} \mathrm{C}\right.$ with $\mathrm{T}_{\max }$ $609=60^{\circ} \mathrm{C}$ and $\mathrm{T}_{\min }=40^{\circ} \mathrm{C}$ ).

610 Assuming a constant $\mathrm{Cp}_{\text {water }}$ of $75.4 \mathrm{~J} / \mathrm{mol} / \mathrm{K}$ and an efficiency of the heat exchanger of $100 \%$, 611 the necessary quantity of water to heat a $100 \mathrm{~m}^{2}$ house would therefore be $2.77 \times 10^{7} \mathrm{~mol}$.

612 We can assess the amount of water that has to be pumped for the two other groups of 613 thermal waters considered earlier with reservoir temperature $\left(\mathrm{T}_{\mathrm{depth}}\right)$ of 90 and $140^{\circ} \mathrm{C}$ using to 614 the following equation:

$$
\left(n_{\text {water }}\right)_{\text {pumped }}=\frac{Q}{C p_{\text {water }} *\left(T_{\text {depth }}-T_{\text {max }}\right)}
$$

615 We found that the amount of water that has to be pumped is $1.85 \times 10^{7}$ and $6.15 \times 10^{6} \mathrm{~mol}$ 616 respectively. Using the average $\mathrm{CO}_{2}$ concentration estimated for each thermal water groups (2 $617 \times 10^{-4}, 5 \times 10^{-3}, 8 \times 10^{-1} \mathrm{~mol} / \mathrm{L}$ ), we can estimate the amount of natural $\mathrm{CO}_{2}$ degassed during 
618 household heating ranging between $1.0 \times 10^{2}$ and $8.9 \times 10^{4} \mathrm{~mol}$. The estimated amount of $\mathrm{CO}_{2}$

619 released from geothermal waters used in heating is lower by 1 to 2 orders of magnitude than

620 the amount of $\mathrm{CO}_{2}$ generated by a natural gas furnace for the two first groups of thermal waters

$621\left(\mathrm{~T}_{\text {depth }}<130^{\circ} \mathrm{C}\right.$ ) (Figure 11). However, similar quantity of $\mathrm{CO}_{2}$ could be released from the

622 thermal waters with the higher $\mathrm{T}_{\text {depth }}$ as those produced by a natural gas furnace.

623 These estimations of $\mathrm{CO}_{2}$ emissions in this simple practical application of heating a $100 \mathrm{~m}^{2}$

624 house show that the geothermal energy is globally a cleaner energy than natural gas but might

625 release as much $\mathrm{CO}_{2}$ as a natural gas furnace in certain conditions (high reservoir temperature

626 and $f \mathrm{CO}_{2}$ ). These estimations are based on possible gas venting during the heat production,

627 which are usually neglected in life cycle assessment of carbon intensity of geothermal system

628 (McCay et al., 2019).

629 These estimations, giving us the order of magnitude of $\mathrm{CO}_{2}$ emissions that could be generated

630 by the investigated geothermal systems, lead to explore possible exploitations of the geothermal

631 resource. Direct electricity production (e.g. enhanced geothermal systems) might be considered

632 for the thermal waters with the highest reservoir temperature $\left(\mathrm{T}_{\text {depth }}=140^{\circ} \mathrm{C}\right)$ emitting large

633 quantity of $\mathrm{CO}_{2}$. This use would have to be coupled to $\mathrm{CO}_{2}$ capture and storage to make it a

634 renewable and clean energy.

635

\section{Conclusions}

637 Our study provides the first characterization of the reservoir conditions $(\mathrm{T}$, $\mathrm{P}$, and 638 geochemistry) for the thermal waters in the central part of the Betic Cordillera. The $f \mathrm{CO}_{2}$ at 639 depth were tentatively assessed with both a chemical geobarometer and direct geochemical 640 simulations. The variation of $f \mathrm{CO}_{2}$ ranges from approximatively $6 \times 10^{-3}$ to $10^{2}$ at the scale of 641 the area. Based on the geology of the thermal water locations and the results of the 642 geothermometrical and thermodynamic geochemical simulations three groups of waters have 
been determined.

644 The group of the thermal waters located in the sedimentary basin has estimated reservoir temperatures ranging from approximatively 70 to $90^{\circ} \mathrm{C}$ and $f \mathrm{CO}_{2}$ varying between $6 \times 10^{-2}$ and $6 \times 10^{-1}$. The estimated variations in $f \mathrm{CO}_{2}$ between the depth and the surface $\left(\Delta f \mathrm{CO}_{2}\right)$ were quite 647 similar considering both the dolomite buffer and carbonate/alumino-silicate buffer for the 648 thermal waters in the Granada Basin. A mineral assemblage buffering at depth mainly composed of carbonates, evaporites, and quartz characterizes this system.

The group of waters located in the graben in the Alpujárride Complex presents the lowest reservoir temperature of $55-60^{\circ} \mathrm{C}$ and $f \mathrm{CO}_{2}$ ranging from $5 \times 10^{-3}$ to $7 \times 10^{-2}$, depending of the considered buffering minerals. The $\Delta f \mathrm{CO}_{2}$ between the depth and the surface is higher with the dolomite buffer than with the carbonate and alumino-silicate buffer. The buffering mineral assemblage at depth is estimated to be carbonates, quartz, and $\mathrm{Ca}$ alumino-silicates.

On the other hand, the group of waters located at contact with metamorphic complexes shows the highest reservoir temperature of $130-140^{\circ} \mathrm{C}$ and $f \mathrm{CO}_{2}$ ranging from approximatively 1 to 100 . The $\Delta f \mathrm{CO}_{2}$ between the depth and the surface is lower with the dolomite buffer than with the carbonate and alumino-silicate buffer. The buffering mineral assemblage in the reservoir might be dolomite, quartz, $\mathrm{Mg}$ and $\mathrm{Ca}$ alumino-silicates.

This study highlights the importance of evaluating the mineral buffers in the reservoir conditions of the geothermal systems. The mineral assemblage at equilibrium in the reservoir conditions constrains the estimated $\mathrm{CO}_{2}$ generation and release at depth. In the case study of the Central Betic Cordillera, $\mathrm{CO}_{2}$ degassing is more constrained in the evaporitic basins thanks 664 to a strong carbonate/evaporite/quartz buffer than in the surrounding areas of the basins where 665 the alumino-silicates play a non-negligible role. Moreover, we pointed out the key role of the reservoir temperature on the estimation of the reactions between $\mathrm{CO}_{2}$, water, and rocks for the geothermal systems in sedimentary basins. 
669 household heating purpose indicate that the geothermal energy is globally a clean energy but

670 might release as much $\mathrm{CO}_{2}$ as a natural gas furnace for the thermal waters with the highest

671 reservoir temperature. This study points out the importance to estimate properly the amount of

$672 \mathrm{CO}_{2}$ degassing in geothermal waters depending of the reservoir conditions. Our results

673 highlight the importance of considering geochemical estimates for heat exchanger design. In

674 the case of thermal waters with the highest temperatures and high $\mathrm{CO}_{2}$ contents, heat

675 exchangers allowing to maintain fluids under pressure might be preferred to avoid $\mathrm{CO}_{2}$ release

676 in the atmosphere.

677 


\section{Acknowledgments:}

679 The Authors thank N. Labourdette and E. Aubry for their help in water analyses and Claudio 680 Inguaggiato for helping collecting gas samples during the sampling survey. The Authors are 681 also grateful to M. Rouelle, M. Azaroual, and P. Sarda for the fruitful discussions during various 682 stages of this study. The Authors thank the two Reviewers for their fruitful comments that 683 helped to improve the quality and the clarity of the manuscript. This work was supported by 684 IFPEN and Sorbonne Université. We also thank the Istituto Nazionale di Geofisica e 685 Vulcanologia - Palermo (INGV) for gas analyses. 


\section{References:}

Ármannsson, H., 2018. An overview of carbon dioxide emissions from Icelandic geothermal areas. Appl. Geochemistry 97, 11-18. https://doi.org/10.1016/j.apgeochem.2018.07.013

Ármannsson, H., 2003. CO2 emission from geothermal plants, in: International Geothermal Conference. pp. 56-62.

Arnórsson, S., Gunnlaugsson, E., Svavarsson, H., 1983. The chemistry of geothermal waters in Iceland. III. Chemical geothermometry in geothermal investigations. Geochim. Cosmochim. Acta 47, 567-577. https://doi.org/10.1016/0016-7037(83)90278-8

Arrizabalaga, I., De Gregorio, M., García del la Noceda, C., Hidalgo, R., Urchueguía, J.F., 2015. Country Update for the Spanish Geothermal Sector, in: World Geothermal Congress 2015. p. 9.

Asta, M.P., Gimeno, M.J., Auqué, L.F., Gómez, J., Acero, P., Lapuente, P., 2012. Hydrochemistry and geothermometrical modeling of low-temperature Panticosa geothermal system (Spain). J. Volcanol. Geotherm. Res. 235-236, 84-95. https://doi.org/10.1016/j.jvolgeores.2012.05.007

Auqué, L.F., Acero, P., Gimeno, M.J., Gómez, J.B., Asta, M.P., 2009. Hydrogeochemical modeling of a thermal system and lessons learned for $\mathrm{CO} 2$ geologic storage. Chem. Geol. 268, 324-336. https://doi.org/10.1016/j.chemgeo.2009.09.011

Azañón, J.M., Crespo-Blanc, A., 2000. Exhumation during a continental collision inferred from the tectonometamorphic evolution of the Alpujarride Complex in the central Betics (Alboran Domain, SE Spain). Tectonics 19, 549-565. https://doi.org/10.1029/2000TC900005

Azañón, J.M., García-Dueñas, V., Goffé, B., 1998. Exhumation of high-pressure metapelites and coeval crustal extension in the Alpujarride complex (Betic Cordillera). Tectonophysics 285, 231-252. https://doi.org/10.1016/S0040-1951(97)00273-4

Battistel, M., Hurwitz, S., Evans, W.C., Barbieri, M., 2016. The chemistry and isotopic composition of waters in the low-enthalpy geothermal system of Cimino-Vico Volcanic District, Italy. J. Volcanol. Geotherm. Res. 328, 222-229. https://doi.org/10.1016/j.jvolgeores.2016.11.005

Benavente Herrera, J., Sanz de Galdeano, C., 1985. Relacion de las direcciones de karstificacion y del termalismo con la fracturacion en las Cordilleras Beticas. Estud. Geológicos 41, 177188.

Bjorlykke, K., Egeberg, P.K., 1993. Quartz cementation in sedimentary basins. Am. Assoc. Pet. Geol. Bull. 77, 1538-1548. 
Blasco, M., Auqué, L.F., Gimeno, M.J., Acero, P., Asta, M.P., 2017. Geochemistry, geothermometry and influence of the concentration of mobile elements in the chemical characteristics of carbonate-evaporitic thermal systems. The case of the Tiermas geothermal system (Spain). Chem. Geol. 466, 696-709. https://doi.org/10.1016/J.CHEMGEO.2017.07.013

Blasco, M., Gimeno, M.J., Auqué, L.F., 2018. Low temperature geothermal systems in

Braga, J.C., Martín, J.M., Quesada, C., 2003. Patterns and average rates of late Neogene-calculations. Insights from the Arnedillo thermal waters (Spain). Sci. Total Environ. 615, 526-539. https://doi.org/10.1016/J.SCITOTENV.2017.09.269 Recent uplift of the Betic Cordillera, SE Spain. Geomorphology 50, 3-26. https://doi.org/10.1016/S0169-555X(02)00205-2

Buforn, E., Bezzeghoud, M., Udías, A., Pro, C., 2004. Seismic Sources on the Iberia-African Plate Boundary and their Tectonic Implications. Pure Appl. Geophys. 161, 623-646. https://doi.org/10.1007/s00024-003-2466-1

Campos, J.C.R., 2006. Guía de manantiales de la provincia de Granada: Una visión sobre su origen y naturaleza. Publicaciones de Diputación Provincial de Granada.

Capasso, G., Favara, R., Grassa, F., Inguaggiato, S., Longo, M., 2005. On-line technique for preparing and measuring stable carbon isotope of total dissolved inorganic carbon in water samples ( $\delta^{13}$ CTDIC). Ann. Geophys. 48, 159-166.

Capasso, G., Inguaggiato, S., 1998. A simple method for the determination of dissolved gases in natural waters. An application to thermal waters from Vulcano Island. Appl. Geochemistry 13, 631-642. https://doi.org/10.1016/S0883-2927(97)00109-1

Capecchiacci, F., Tassi, F., Vaselli, O., Bicocchi, G., Cabassi, J., Giannini, L., Nisi, B., Chiocciora, G., 2015. A combined geochemical and isotopic study of the fluids discharged from the Montecatini thermal system (NW Tuscany, Italy). Appl. Geochemistry 59, $33-$ 46. https://doi.org/10.1016/j.apgeochem.2015.03.010

Centre d'Expertise en Analyse Environnementale du Québec, 2016. Détermination de la silice réactive dans l'eau: méthode par spectrophotométrie UV-visible, MA. 303 - SiO2 1.0, rév. 1. Ministère du Développement durable, de l'Environnement, de la Lutte contre les changements climatiques.

Cerón, J.C., López-Chicano, M., 2002. Thermal waters in Andalucía. Newsl. Int. Geotherm. Assoc. 48, 4-5.

Chiodini, G., Baldini, A., Barberi, F., Carapezza, M.L., Cardellini, C., Frondini, F., Granieri, 
D., Ranaldi, M., 2007. Carbon dioxide degassing at Latera caldera (Italy): Evidence of geothermal reservoir and evaluation of its potential energy. J. Geophys. Res. 112, 1-17. https://doi.org/10.1029/2006JB004896

757

Chiodini, G., Cioni, R., Guidi, M., Raco, B., Marini, L., 1998. Soil $\mathrm{CO}_{2}$ flux measurements in volcanic and geothermal areas. Appl. Geochemistry 13, 543-552.

Chiodini, G., Frondini, F., Marini, L., 1995a. Theoretical geothermometers and $\mathrm{PCO}_{2}$ indicators for aqueous solutions coming from hydrothermal systems of medium-low temperature hosted in carbonate-evaporite rocks. Application to the thermal springs of the Etruscan Swell, Italy. Appl. Geochemistry 10, 337-346. https://doi.org/10.1016/08832927(95)00006-6

Chiodini, G., Frondini, F., Ponziani, F., 1995b. Deep structures and carbon dioxide degassing in Central Italy. Geothermics 24, 81-94. https://doi.org/10.1016/0375-6505(94)00023-6

Clark, I.D., Fritz, P., 1997. Environmental isotopes in hydrogeology. CRC Press/Lewis Publishers, Boca Raton, FL.

Corbí, H., Lancis, C., García-García, F., Pina, J.-A., Soria, J.M., Tent-Manclús, J.E., Viseras, C., 2012. Updating the marine biostratigraphy of the Granada Basin (central Betic Cordillera). Insight for the Late Miocene palaeogeographic evolution of the Atlantic -Mediterranean seaway.

Geobios

45 , 249-263. https://doi.org/10.1016/j.geobios.2011.10.006

Coudrain-Ribstein, A., Gouze, P., de Marsily, G., 1998. Temperature-carbon dioxide partial pressure trends in confined aquifers. Chem. Geol. 1, 73-89. https://doi.org/https://doi.org/10.1016/S0009-2541(97)00161-7

Cruz-Sanjulián, J., Rossell, L.G., Blasco, J.G., 1972. Aguas termales de la provincia de Granada. Bol. Geológico y Min. T.LXXXIII-III 266-275.

Cruz Sanjulián, J., Granda, J.M., 1979. Temperatura de base de las aguas termales de la provincia de Granada, in: II Simposio Nacional de Hidrogeología. pp. 547-568.

D’Amore, F., Arnórsson, S., Geothermometry, S.A., 2000. Isotopic and Chemical Techniques in Geothermal Exploration. Dev. Use Sampl. Methods, Data Handl. Interpret. Int. At. Energy Agency, Vienna, Austria 152-199.

D'Amore, F., Fancelli, R., Caboi, R., 1987. Observations on the application of chemical geothermometers to some hydrothermal systems in Sardinia. Geothermics 16, 271-282.

Elidemir, S., Güleç, N., 2018. Geochemical characterization of geothermal systems in western Anatolia (Turkey): implications for CO2trapping mechanisms in prospective CO2-EGS sites. Greenh. Gases Sci. Technol. 8, 63-76. https://doi.org/10.1002/ghg.1747 
Fernàndez, M., Marzán, I., Correia, A., Ramalho, E., 1998. Heat flow, heat production, and lithospheric thermal regime in the Iberian Peninsula. Tectonophysics 291, 29-53. https://doi.org/10.1016/s0040-1951(98)00029-8

Fournier, R.O., 1977. Chemical geothermometers and mixing models for geothermal systems. Geothermics 5, 41-50. https://doi.org/10.1016/0375-6505(77)90007-4

Fournier, R.O., Potter, R.W., 1982. An equation correlating the solubility of quartz in water from $25^{\circ}$ to $900^{\circ} \mathrm{C}$ at pressures up to 10,000 bars. Geochim. Cosmochim. Acta 46, 19691973. https://doi.org/10.1016/0016-7037(82)90135-1

Fusari, A., Carroll, M.R., Ferraro, S., Giovannetti, R., Giudetti, G., Invernizzi, C., Mussi, M., Pennisi, M., 2017. Circulation path of thermal waters within the Laga foredeep basin inferred from chemical and isotopic $(\delta 18 \mathrm{O}, \delta \mathrm{D}, 3 \mathrm{H}, 87 \mathrm{Sr} / 86 \mathrm{Sr})$ data. Appl. Geochemistry 78, 23-34. https://doi.org/10.1016/J.APGEOCHEM.2016.11.021

Galindo-Zaldívar, J., Gil, A.J., Sanz de Galdeano, C., Lacy, M.C., García-Armenteros, J.A., Ruano, P., Ruiz, A.M., Martínez-Martos, M., Alfaro, P., 2015. Active shallow extension in central and eastern Betic Cordillera from CGPS data. Tectonophysics 663, 290-301. https://doi.org/10.1016/j.tecto.2015.08.035

Gran, G., 1952. Determination of the equivalence point in potentiometric titrations. Part II. Analyst 77, 661-671. https://doi.org/10.1039/AN9527700661

Harvey, M.C., Rowland, J. V, Chiodini, G., Rissmann, C.F., Bloomberg, S., Fridriksson, T., Oladottir, A.A., 2017. $\mathrm{CO}_{2}$ flux geothermometer for geothermal exploration. Geochim. Cosmochim. Acta 213, 1-16. https://doi.org/10.1016/j.gca.2017.06.025

Hunt, T.M., 2001. Five Lectures on Environmental Effects of Geothermal Utilization, Geothermal Training Programme.

Hutcheon, I.A.N., Shevalier, M., Abercrombie, H.J., 1993. pH buffering by metastable mineralfluid equilibria and evolution of carbon dioxide fugacity during burial diagenesis. Geochim. Cosmochim. Acta 57, 1017-1027.

Inguaggiato, S., Rizzo, A., 2004. Dissolved helium isotope ratios in ground-waters: a new technique based on gas--water re-equilibration and its application to Stromboli volcanic system. Appl. Geochemistry

19 , $665-673$. https://doi.org/10.1016/j.apgeochem.2003.10.009

Lapillonne, B., Pollier, K., Samci, N., 2014. Energy efficiency trends for households in the EU. Enerdata. Retrieved June 22, 2015.

Lix, C., Zuddas, P., Inguaggiato, C., Guichet, X., Benavente, J., Barbier, M., 2018. New insights on Betic Cordillera structure from gas geochemistry. Geochemistry, Geophys. Geosystems 
López-Chicano, M., Bouamama, M., Vallejos, A., Pulido-Bosch, A., 2001a. Factors which determine the hydrogeochemical behaviour of karstic springs. A case study from the Betic Cordilleras, Spain. Appl. Geochemistry 16, 1179-1192. https://doi.org/10.1016/S08832927(01)00012-9

López-Chicano, M., Cerón, J.C., Vallejos, A., Pulido-Bosch, A., 2001b. Geochemistry of thermal springs, Alhama de Granada (southern Spain). Appl. Geochemistry 16, 11531163. https://doi.org/10.1016/S0883-2927(01)00020-8

Marini, L., Chiodini, G., Cioni, R., 1986. New geothermometers for carbonate-evaporite geothermal reservoirs. Geothermics 15, 77-86. https://doi.org/10.1016/03756505(86)90030-1

Martín-Algarra, A., Martín-Martín, M., Andreo, B., Julià, R., González-Gómez, C., 2003. Sedimentary patterns in perched spring travertines near Granada (Spain) as indicators of the paleohydrological and paleoclimatological evolution of a karst massif. Sediment. Geol. 161, 217-228. https://doi.org/10.1016/S0037-0738(03)00115-5

Martín, J.M., Braga, J.C., 1987. Alpujárride carbonate deposits (southern Spain) - Marine Sedimentation in a Triassic Atlantic. Palaeogeogr. Palaeoclimatol. Palaeoecol. 59, $243-$ 260.

McCay, A.T., Feliks, M.E.J., Roberts, J.J., 2019. Life cycle assessment of the carbon intensity of deep geothermal heat systems: A case study from Scotland. Sci. Total Environ. 685, 208-219. https://doi.org/10.1016/j.scitotenv.2019.05.311

Michard, G., 1990. Behaviour of major elements and some trace elements ( $\mathrm{Li}, \mathrm{Rb}, \mathrm{Cs}, \mathrm{Sr}, \mathrm{Fe}$, Mn, W, F) in deep hot waters from granitic areas. Chem. Geol. 89, 117-134. https://doi.org/10.1016/0009-2541(90)90062-C

Michard, G., 1979. Géothermomètres chimiques. Bull. BRGM 2, 183-189.

Parkhurst, D.L., Appelo, C.A.J., others, 2013. Description of input and examples for PHREEQC version 3 - a computer program for speciation, batch-reaction, onedimensional transport, and inverse geochemical calculations. US Geol. Surv. Tech. methods, B. 6, 497. https://doi.org/10.1016/0029-6554(94)90020-5

Pérez del Villar, L., 2009. Almacenamiento geológico de CO2: Análogos del almacenamiento y escape. Fundamentos, ejemplos y aplicaciones para la predicción de riesgos y la evaluación del comportamiento a largo plazo. Congr. Nac. del Medio Ambient.

Prado-Pérez, A.J., Pérez del Villar, L., 2011. Dedolomitization as an analogue process for assessing the long-term behaviour of a $\mathrm{CO} 2$ deep geological storage: The Alicún de las 
Torres thermal system (Betic Cordillera, Spain). Chem. Geol. 289, 98-113. https://doi.org/10.1016/j.chemgeo.2011.07.017

Rimstidt, J.D., Barnes, H.L., 1980. The kinetics of silica-water reactions. Geochim. Cosmochim. Acta 44.

Rodríguez-Fernández, J., Sanz de Galdeano, C., 2006. Late orogenic intramontane basin development: the Granada basin, Betics (southern Spain). Basin Res. 18, 85-102. https://doi.org/10.1111/j.1365-2117.2006.00284.x

Sánchez Guzmán, J., García de la Noceda, C., 2010. The Evolution of Geothermal Energy in Spain - Country Update (2005-2009), in: Proceedings World Geothermal Congress.

Sanz de Galdeano, C., 2008. The Cadiz-Alicante fault: an important discontinuity in the Betic Cordillera. Rev. la Soc. Geológica España 21.

Sanz de Galdeano, C., 1990. Geologic evolution of the Betic Cordilleras in the Western Mediterranean, Miocene to the present. Tectonophysics 172, 107-119. https://doi.org/10.1016/0040-1951(90)90062-D

Sanz de Galdeano, C., Peláez, J.A., 2011. Fallas activas en la Cordillera Bética: una aproximación a partir de la información tectónica y sísmica. Editorial Universidad de Granada.

Sanz de Galdeano, C., Peláez, J.A., 2011. Fallas activas en la Cordillera Bética: una aproximación a partir de la información tectónica y sísmica.

Sanz de Galdeano, C., Vera, J.A., 1992. Stratigraphic record and palaeogeographical context of the Neogene basins in the Betic Cordillera, Spain. Basin Res. 4, 21-36. https://doi.org/10.1111/j.1365-2117.1992.tb00040.x

Seward, T.M., Kerrick, D.M., 1996. Hydrothermal $\mathrm{CO}_{2}$ emission from the Taupo volcanic zone, New Zealand. Earth Planet. Sci. Lett. 139, 105-113.

Tole, M.P., Ármannsson, H., Zhong-He, P., Arnórsson, S., 1993. Fluid/mineral equilibrium calculations for geothermal fluids and chemical geothermometry. Geothermics 22, 17-37.

Verma, M.P., 2000a. Chemical thermodynamics of silica: A critique on its geothermometer. Geothermics 29, 323-346. https://doi.org/10.1016/S0375-6505(99)00064-4

Verma, M.P., 2000b. Limitations in applying silica geothermometers for geothermal reservoir evaluation, in: Proceedings, 25th Workshop on Geothermal Reservoir Engineering, Stanford University, Stanford. pp. 24-26. 
890 Figure 1: Location of the thermal water samples in the Central Betic Cordillera and geological

891 map of the area modified after Sanz de Galdeano and Peláez (2011).

892 Figure 2: Piper diagram of the thermal waters from Central Betic Cordillera. Circles and 893 triangles correspond to springs and wells respectively.

894 Figure 3: Evolution of the mineral saturation indices with temperature for the thermal waters 895 located in the evaporitic Granada Basin by geothermometrical modeling.

896 Figure 4: Evolution of the mineral saturation indices with temperature for the thermal waters 897 located (a) in the graben in the Alpujárride Complex and (b) on the contacts of the 898 metamorphic complexes.

899 Figure 5: Relationship between $f \mathrm{CO}_{2}$ and temperature $\left({ }^{\circ} \mathrm{C}\right)$, for the outlet (crosses) and 900 reservoir (circles) conditions considering dolomite equilibrium in depth.

901 Figure 6: Relationship between $f \mathrm{CO}_{2}$ and temperature $\left({ }^{\circ} \mathrm{C}\right)$ for the outlet (crosses) and 902 reservoir (circles) conditions considering equilibrium with calcite, dolomite, quartz, kaolinite, 903 and Mg-chlorite in depth.

904 Figure 7: Relationship between the variations of $f \mathrm{CO}_{2}$ calculated between steps 1 and 3 of the 905 hydrogeochemical modeling, $\Delta f \mathrm{CO}_{2}$ and the reservoir temperature. The light gray squares 906 correspond to equilibrium with dolomite and the dark gray squares with calcite, dolomite, 907 quartz, kaolinite, and $\mathrm{Mg}$-chlorite, both in the reservoir conditions. The variability in $\Delta f \mathrm{CO}_{2}$ is 908 expressed for the three groups of waters with average reservoir temperature of: $55^{\circ} \mathrm{C}$ (blue), $90985^{\circ} \mathrm{C}$ (yellow), and $135^{\circ} \mathrm{C}$ (red).

910 Figure 8: Evolution of the mineral saturation indices with temperature for the thermal waters 911 located in the evaporitic Granada Basin by geothermometrical modeling with theoretical $\mathrm{CO}_{2}$ 912 addition $(1 \mathrm{mmol} / \mathrm{L})$ to compensate possible $\mathrm{CO}_{2}$ outgassing during the ascent of the waters.

913 Figure 9: Evolution of the mineral saturation indices with temperature for the thermal waters 914 located in the Valle de Lecrin graben by geothermometrical modeling with theoretical $\mathrm{CO}_{2}$ 915 addition $(0.5 \mathrm{mmol} / \mathrm{L})$ to compensate possible $\mathrm{CO}_{2}$ outgassing during the ascent of the waters

916 Figure 10: Evolution of the mineral saturation indices with temperature for the thermal waters 917 located on the contacts of the metamorphic complexes. Geothermometrical modeling with 918 theoretical $\mathrm{CO}_{2}$ addition to compensate possible $\mathrm{CO}_{2}$ outgassing during the ascent of the 919 waters.

920 Figure 11: Comparison of $\mathrm{CO}_{2}$ emissions from heating a $100 \mathrm{~m}^{2}$ house using the investigated 921 thermal waters and a natural gas furnace. 


\section{$923 \quad$ Figure 1}

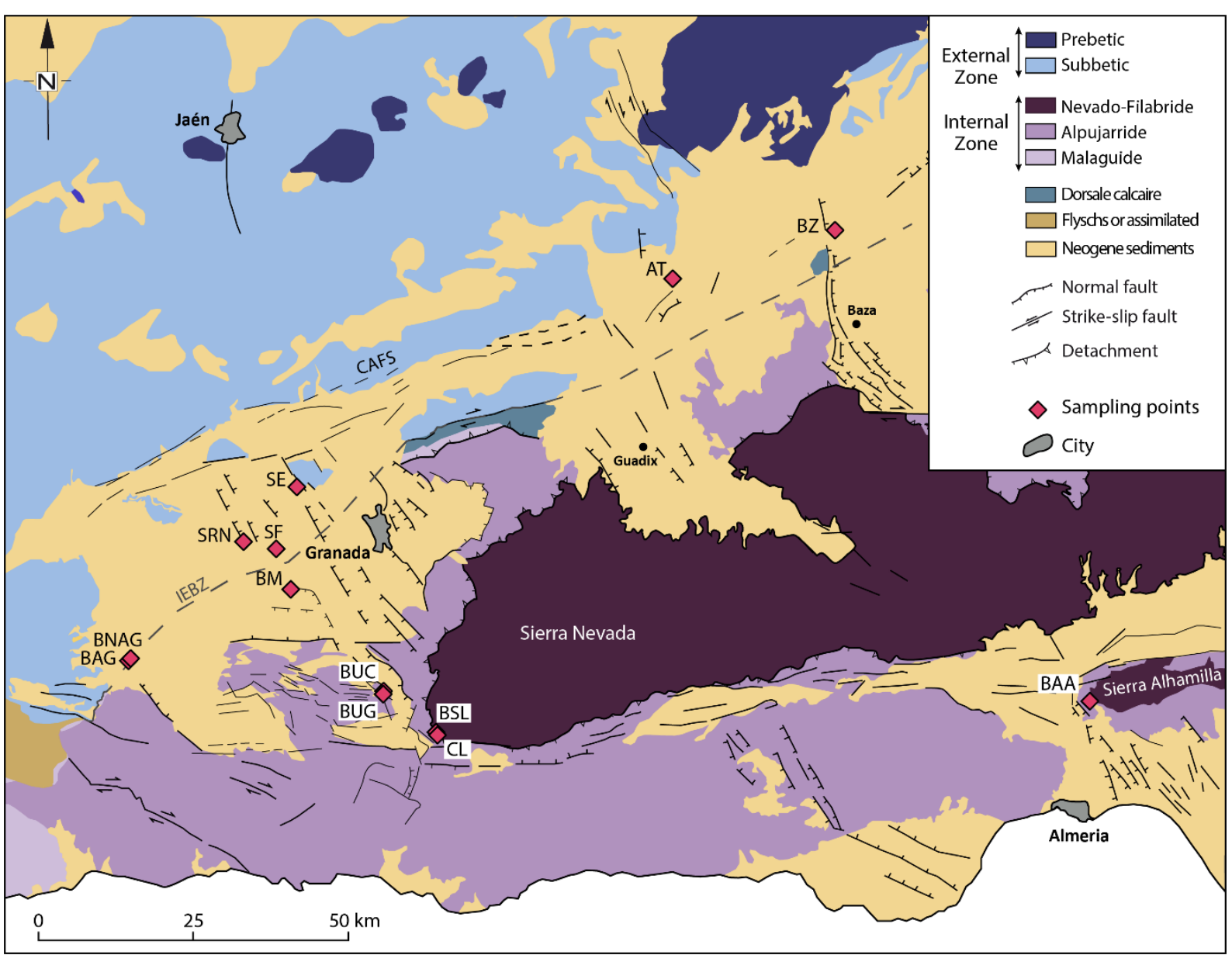




\section{Figure 2}

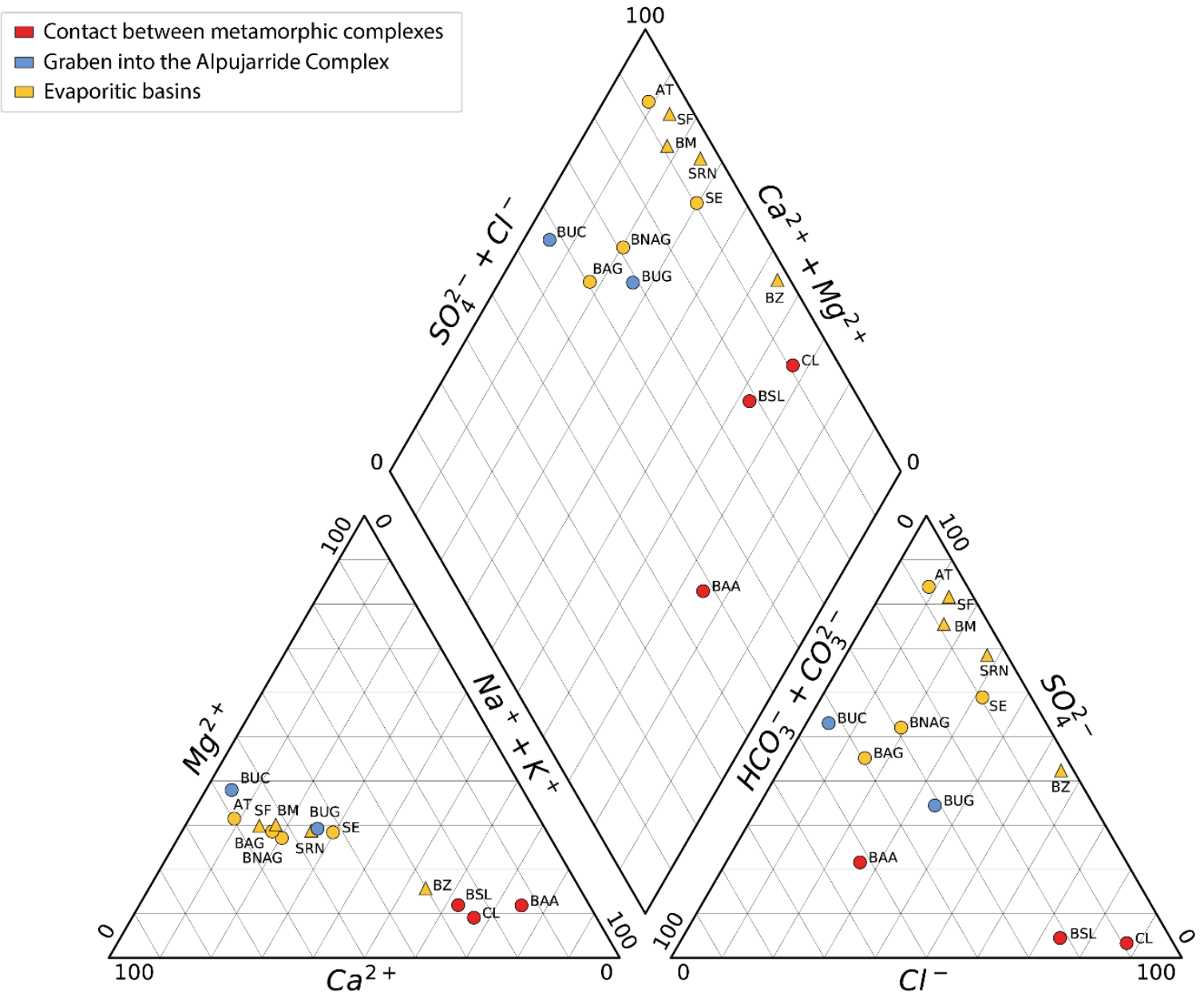



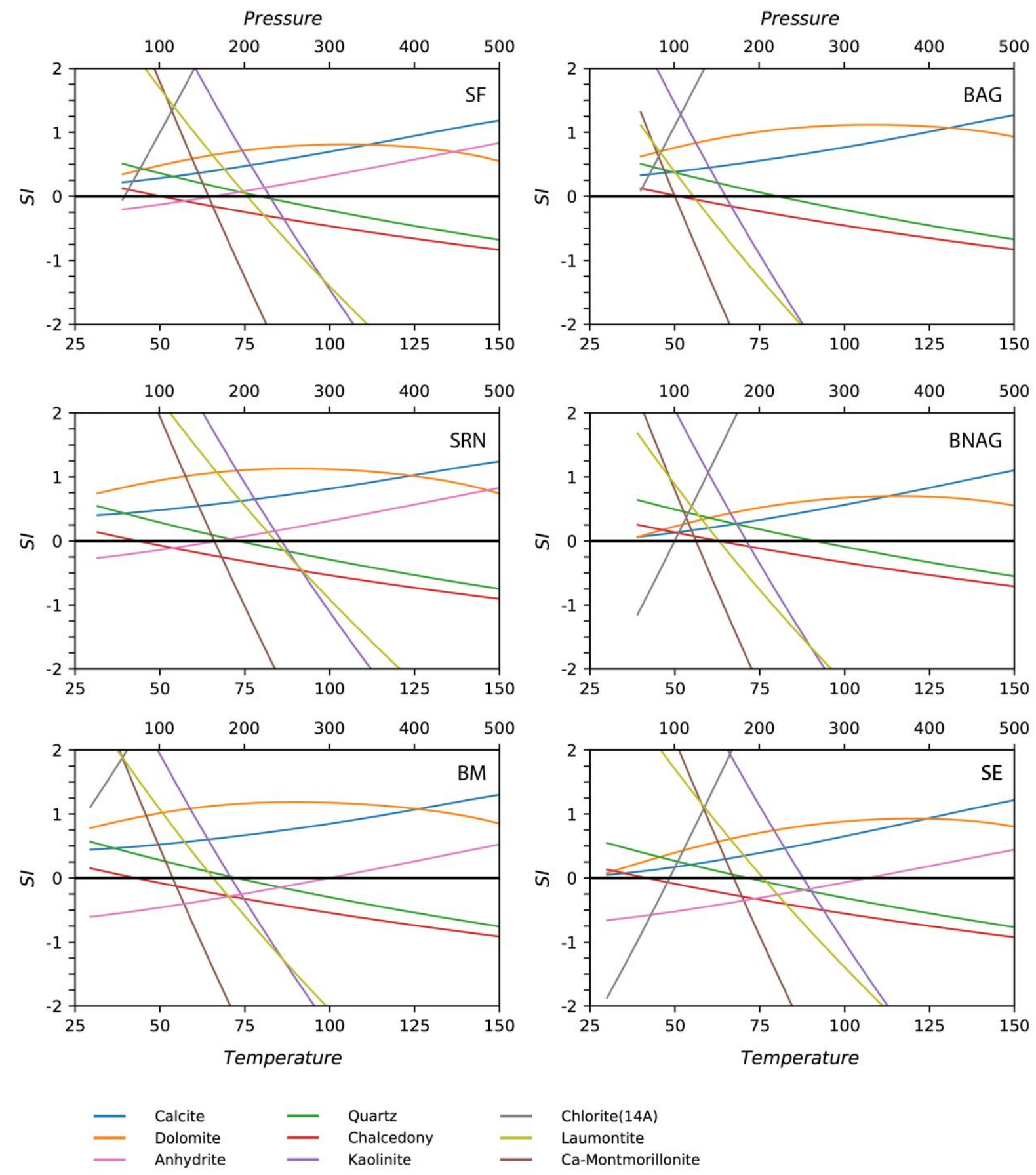
Figure 4
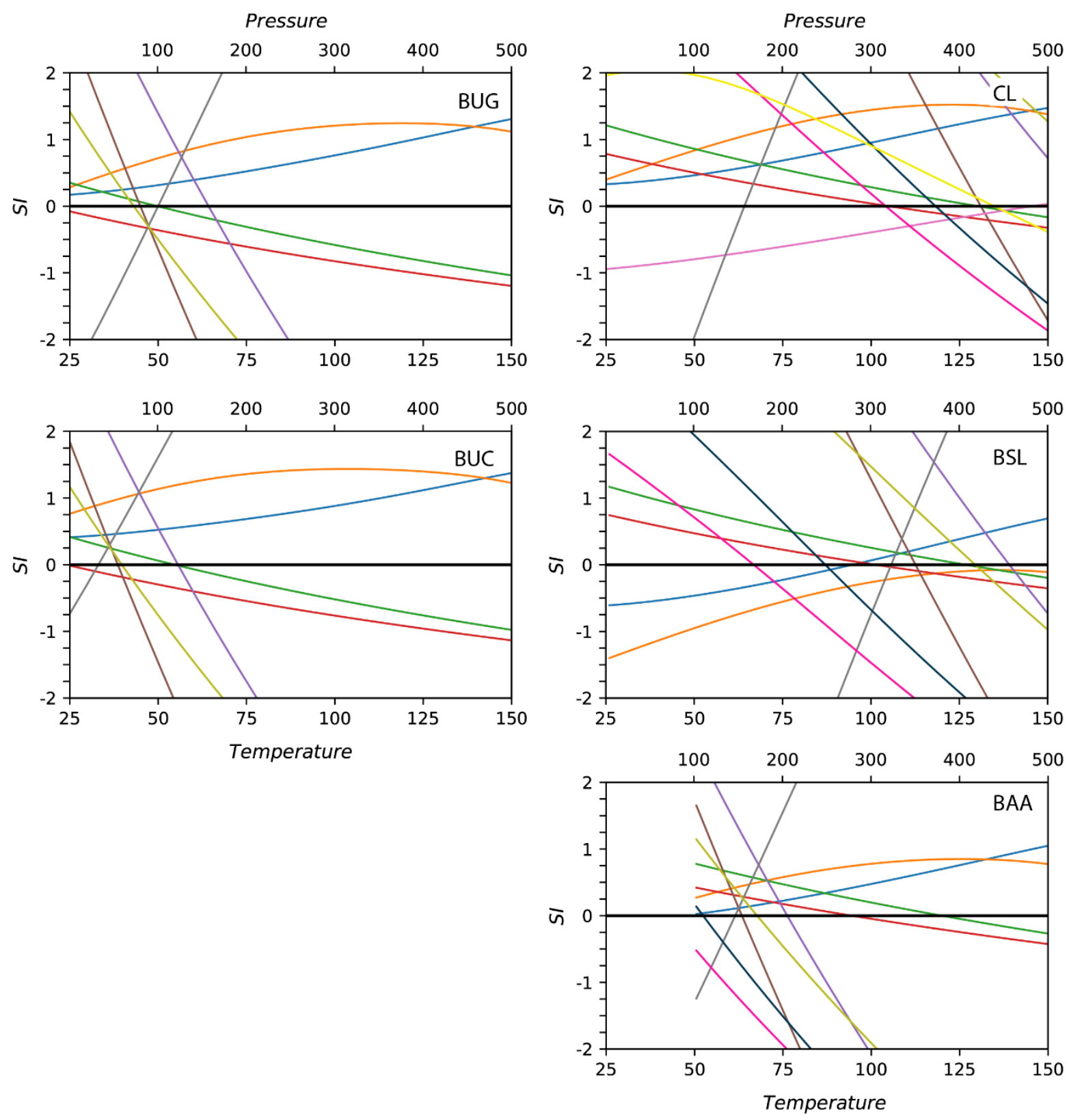

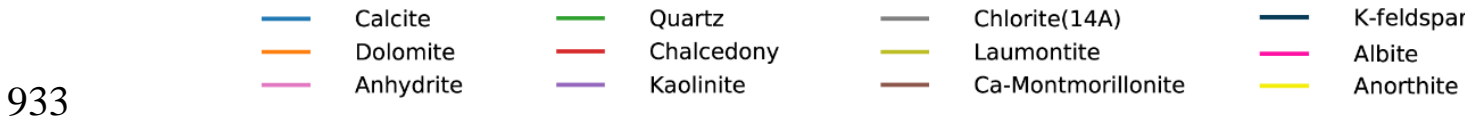


$935 \quad$ Figure 5

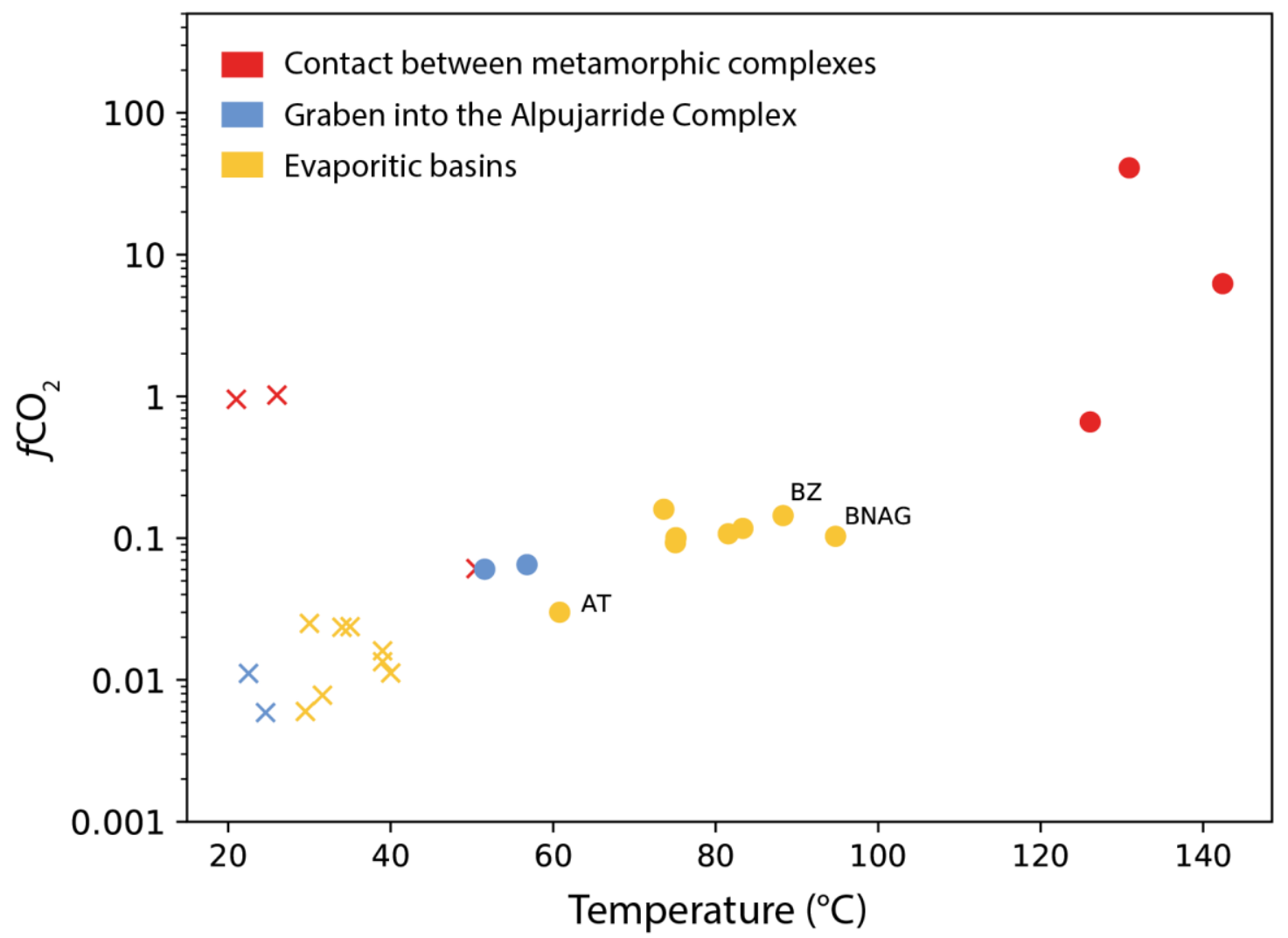

936

937 
$938 \quad$ Figure 6

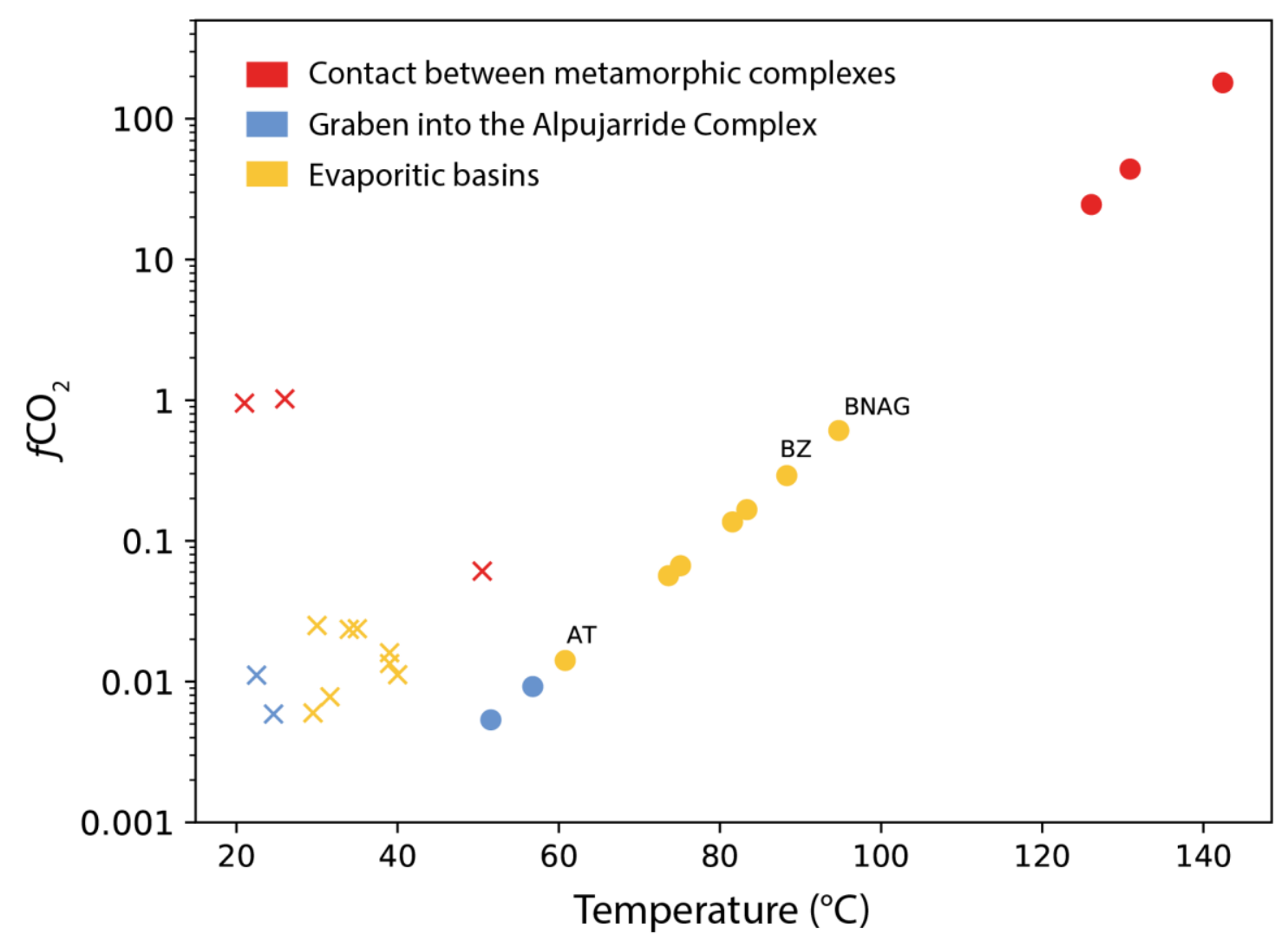

939

940 
$941 \quad$ Figure 7

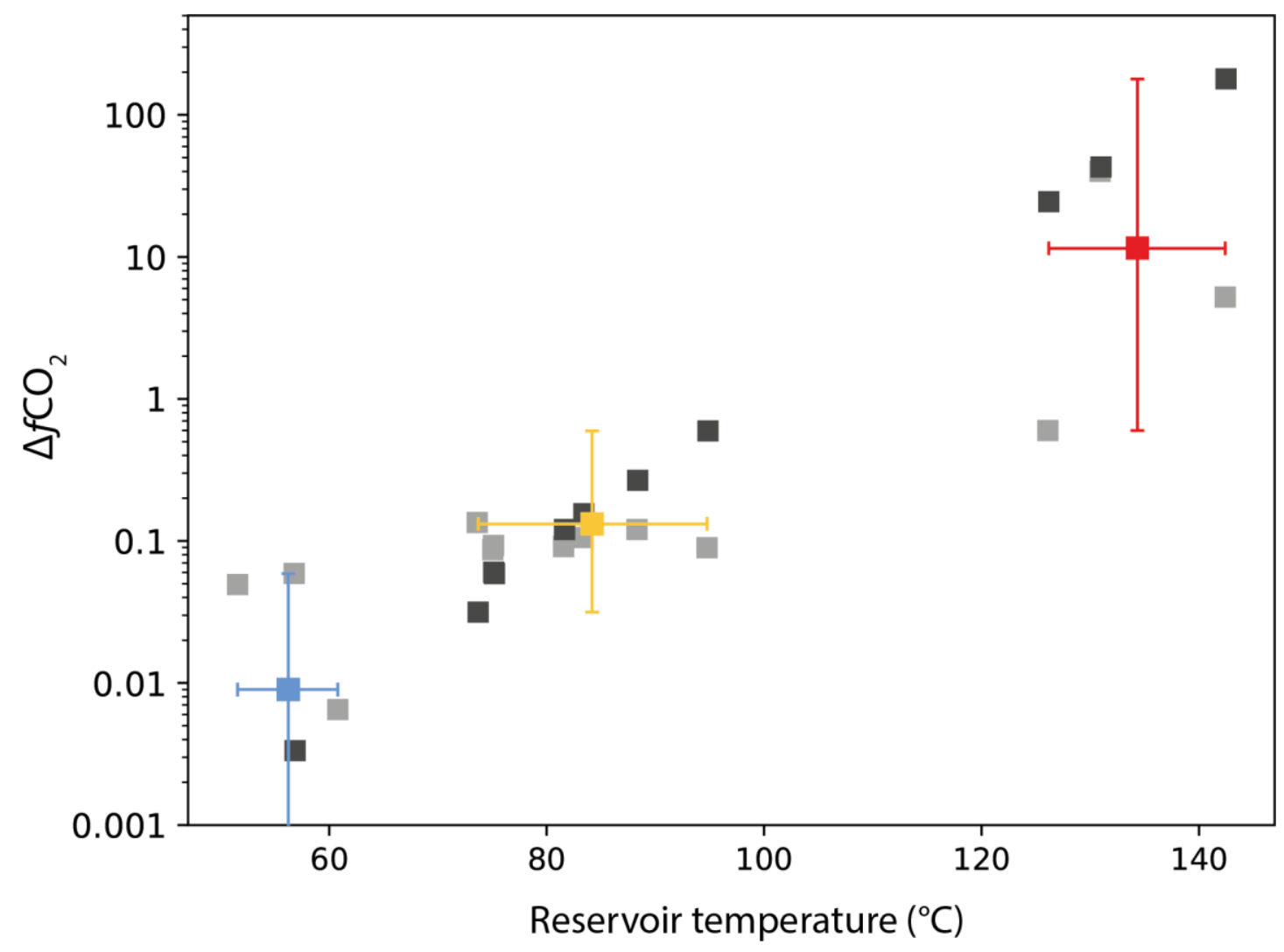

942

943 
Figure 8
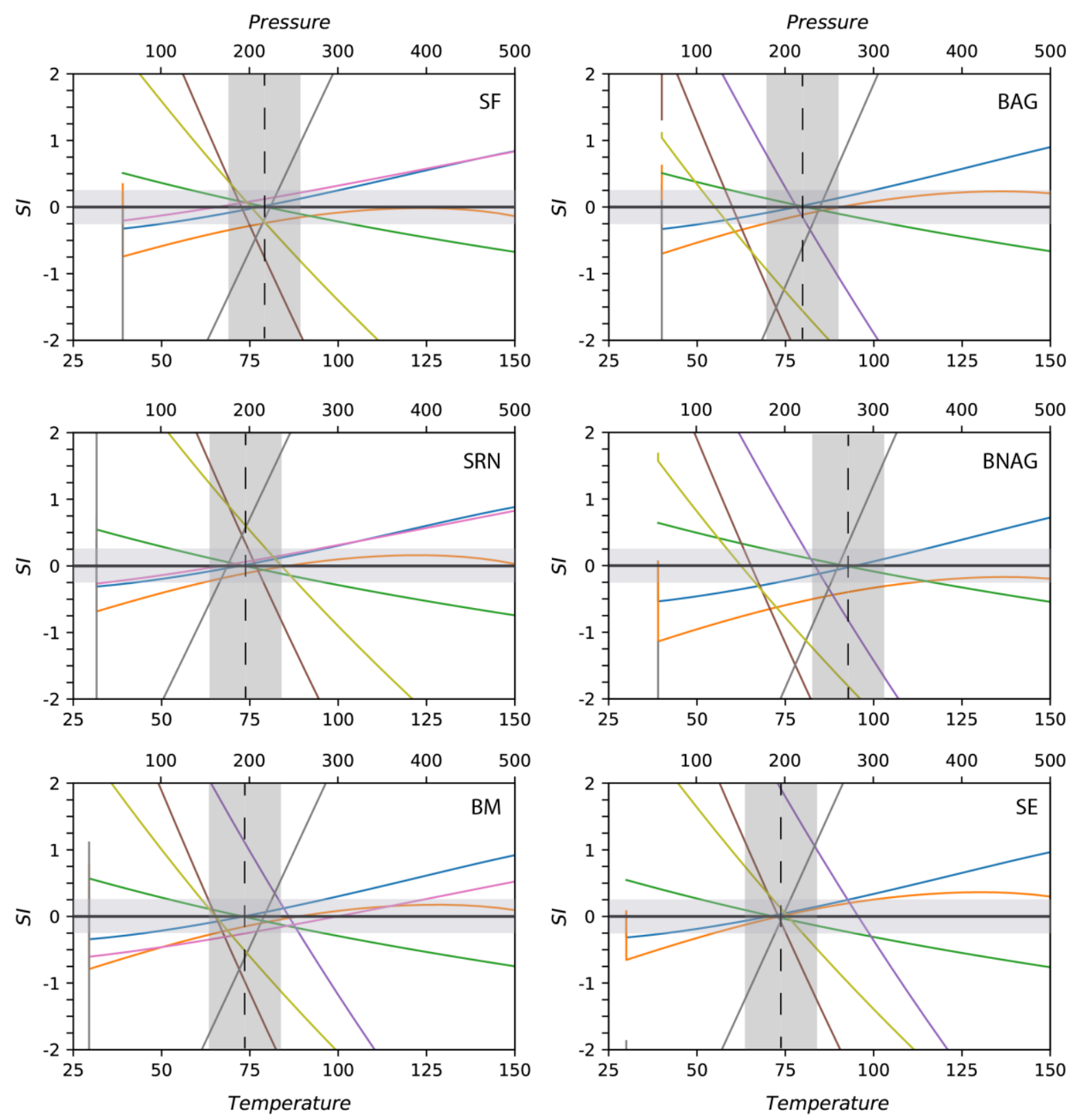

945

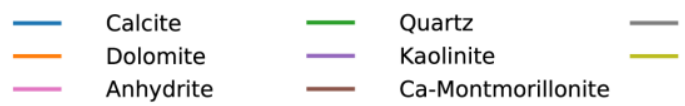

Chlorite(14A)

Laumontite

946 
Figure 9
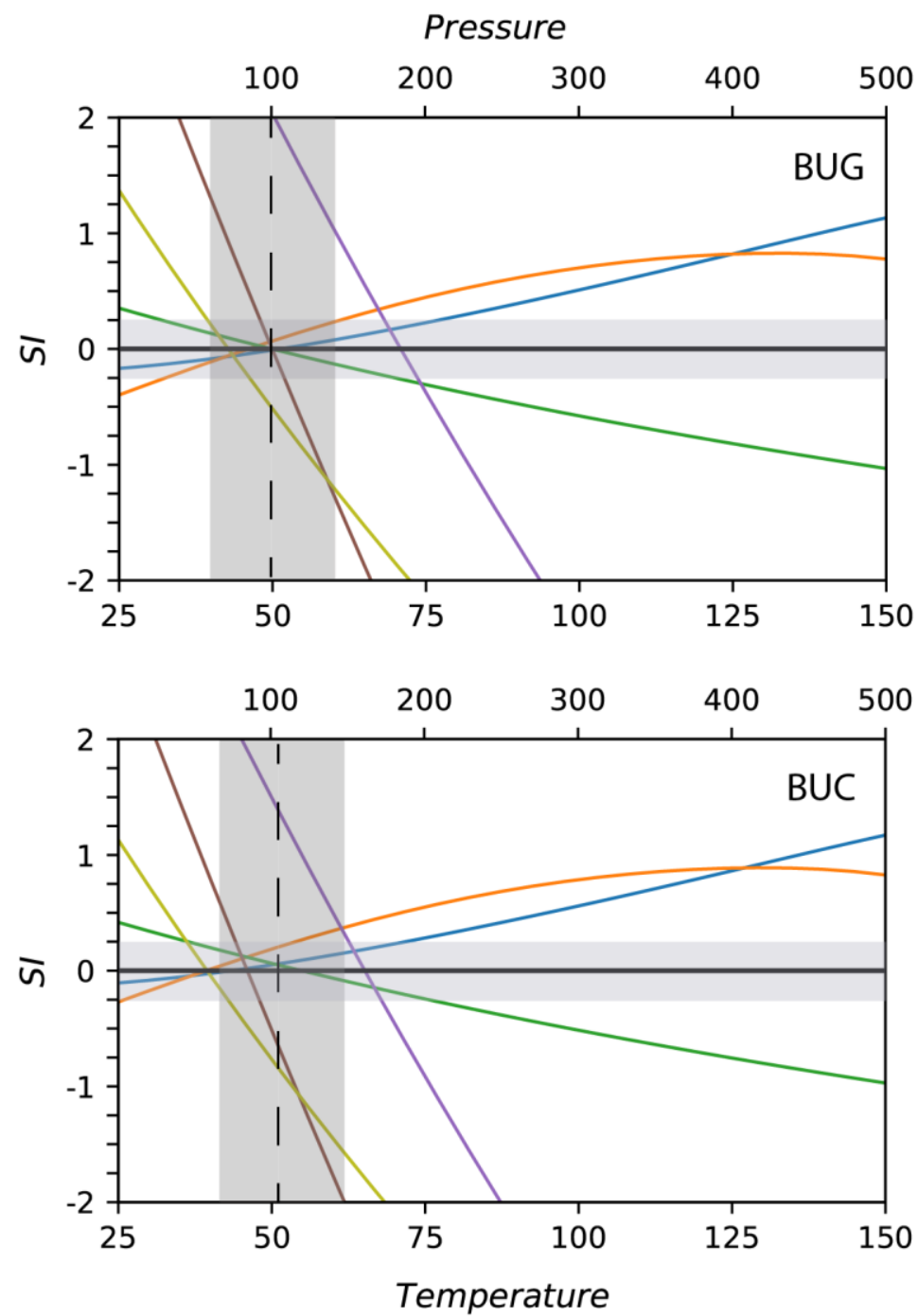

948

$\begin{array}{lll}\text { Calcite } & - & \text { Ca-Montmorillonite } \\ \text { Dolomite } & - & \text { Kaolinite } \\ \text { Quartz } & - & \text { Laumontite }\end{array}$

949 

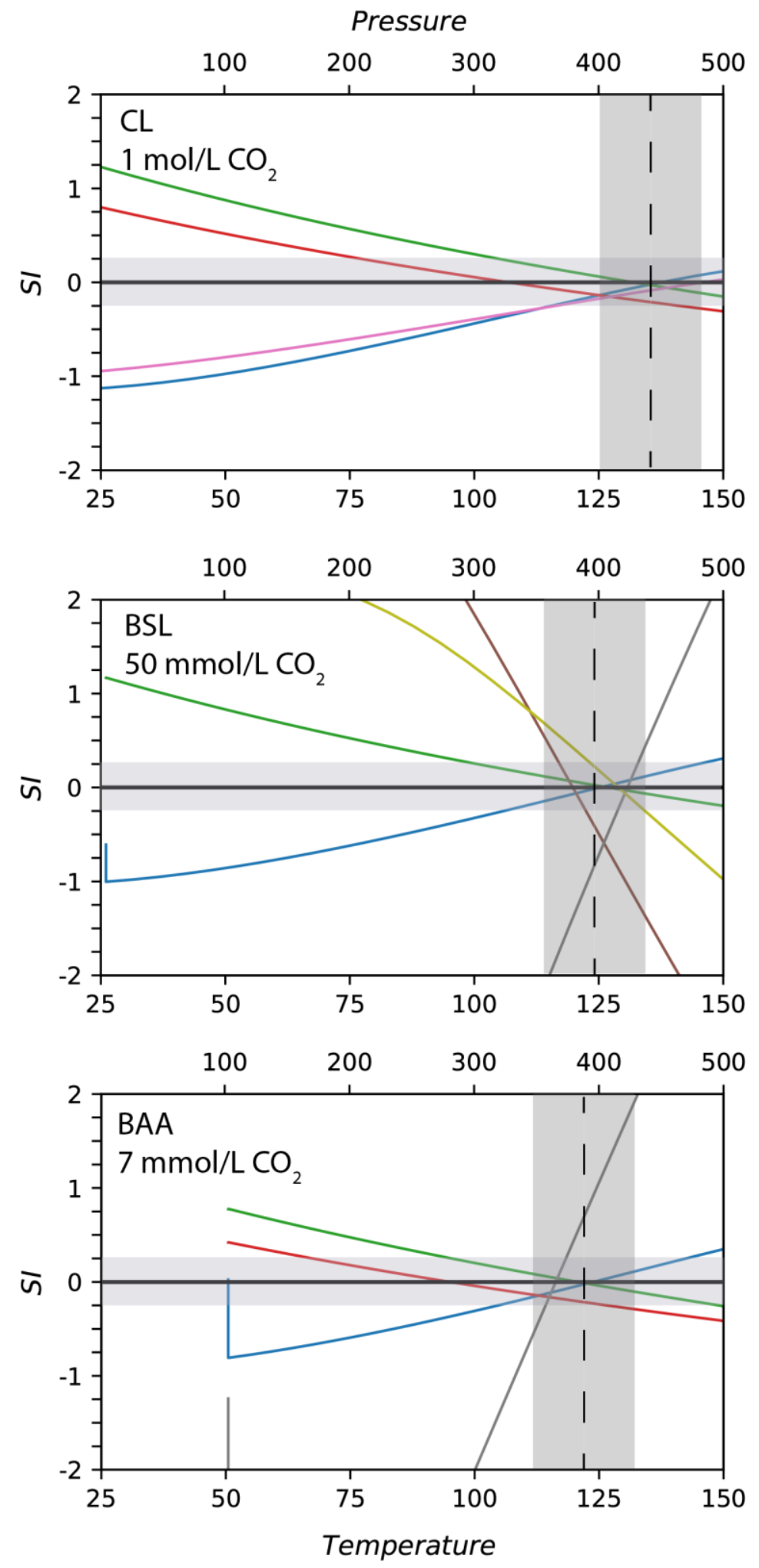

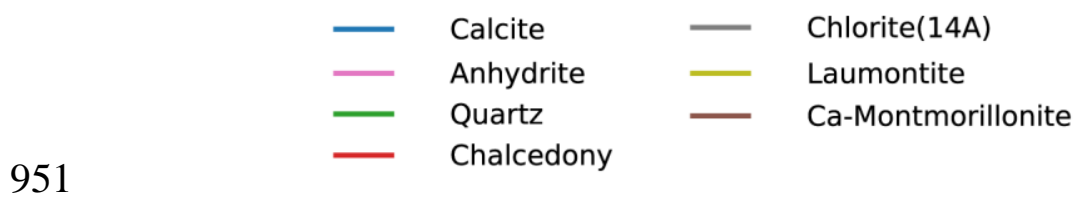


953 Figure 11

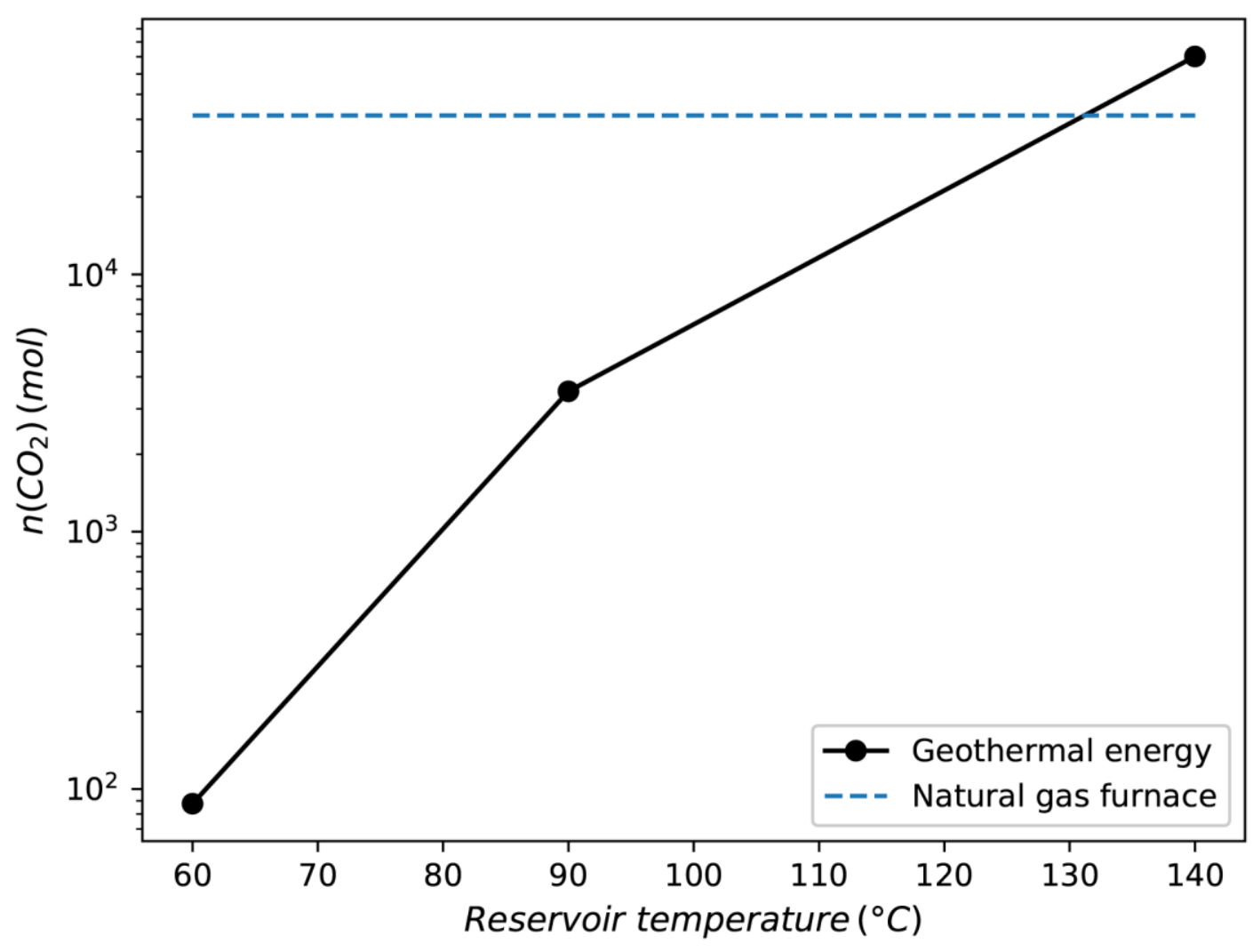

954 


\begin{tabular}{|c|c|c|c|c|c|c|c|c|c|c|c|c|c|c|c|c|c|c|c|c|}
\hline Sample and location & Code & Type & \begin{tabular}{|c|} 
Depth \\
(m) \\
\end{tabular} & $\begin{array}{c}\text { Temp. } \\
\left({ }^{\circ} \mathrm{C}\right) \\
\end{array}$ & pH & EC & $\mathrm{Ca}$ & Mg & $\mathbf{N a}$ & $\mathbf{K}$ & Alk. & $\mathrm{Cl}$ & $\mathrm{SO}_{4}$ & $\mathbf{S i}$ & Al & Ba & $\mathbf{F e}$ & $\mathbf{S r}$ & TDS & CBE \\
\hline \multicolumn{21}{|l|}{ Contacts metamorphic complexes } \\
\hline $\begin{array}{c}\text { Banos Salado de Lanjaron } \\
36^{\circ} 55.4189^{\prime} \mathrm{N} ; 3^{\circ} 29.5869^{\prime} \mathrm{W}\end{array}$ & BSL & $\mathrm{S}$ & & 26 & 5.8 & 8.18 & 6.59 & 3.06 & 29.5 & 2.60 & 12.9 & 44.0 & 1.31 & 1.56 & $8.85 \mathrm{E}-03$ & $1.04 \mathrm{E}-03$ & $3.13 \mathrm{E}-01$ & 0.19 & 3.72 & 7.29 \\
\hline $\begin{array}{c}\text { Capuchina de Lanjaron } \\
36^{\circ} 55.1523^{\prime} \mathrm{N}, 3^{\circ} 29.4182^{\prime} \mathrm{W}\end{array}$ & $\mathrm{CL}$ & $S$ & & 21 & 6.1 & 34.15 & 32.6 & 12.3 & 167 & 14.0 & 28.7 & 275 & 5.24 & 1.53 & 7.13E-02 & 7.34E-04 & $4.98 \mathrm{E}-01$ & 0.62 & 18.17 & 7.40 \\
\hline $\begin{array}{c}\text { Banos de Alhamilla } \\
36^{\circ} 57.6531^{\prime} \mathrm{N} ; 2^{\circ} 23.7875^{\prime} \mathrm{W}\end{array}$ & BAA & $S$ & & 51 & 7.1 & 1.92 & 0.88 & 0.78 & 9.65 & 0.23 & 7.93 & 3.99 & 1.64 & 1.38 & 4.92E-04 & $4.62 \mathrm{E}-04$ & $9.66 \mathrm{E}-04$ & 0.02 & 1.15 & 7.04 \\
\hline Graben into Alp. Complex & & & & & & & & & & & & & & & & & & & & \\
\hline $\begin{array}{c}\text { Banos Urquizar Chico } \\
36^{\circ} 58.3477^{\prime} \mathrm{N} ; 3^{\circ} 34.5347^{\prime} \mathrm{W}\end{array}$ & BUC & $S$ & & 25 & 7.6 & 0.99 & 2.62 & 1.75 & 0.42 & 0.05 & 3.99 & 0.41 & 2.49 & 0.27 & 6.99E-04 & $2.28 \mathrm{E}-04$ & b.d.1 & 0.05 & 0.68 & 0.87 \\
\hline $\begin{array}{c}\text { Banos Urquizar Grande } \\
36^{\circ} 58.2261^{\prime} \mathrm{N} ; 3^{\circ} 34.5854^{\prime} \mathrm{W}\end{array}$ & BUG & $S$ & & 23 & 7.3 & 1.50 & 2.92 & 1.92 & 3.22 & 0.22 & 4.21 & 4.66 & 2.33 & 0.24 & $1.23 \mathrm{E}-03$ & $2.33 \mathrm{E}-04$ & b.d.l & 0.04 & 0.91 & 1.49 \\
\hline Evaporitic basin & & & & & & & & & & & & & & & & & & & & \\
\hline $\begin{array}{c}\text { Banos de la Malaha } \\
37^{\circ} 06.2946^{\prime} \mathrm{N}, 3^{\circ} 43.6034^{\prime} \mathrm{W}\end{array}$ & $\mathrm{BM}$ & $\mathrm{W}$ & 200 & 30 & 7.4 & 3.08 & 8.05 & 4.59 & 5.25 & 0.22 & 2.89 & 5.10 & 12.1 & 0.45 & $1.60 \mathrm{E}-03$ & $1.18 \mathrm{E}-04$ & $2.98 \mathrm{E}-02$ & 0.16 & 2.13 & 2.35 \\
\hline $\begin{array}{c}\text { Santa Fe } \\
37^{\circ} 09.3813^{\prime} \mathrm{N} ; 3^{\circ} 45.2023^{\prime} \mathrm{W}\end{array}$ & $\mathrm{SF}$ & $\mathrm{W}$ & 510 & 39 & 7.0 & 4.69 & 13.7 & 7.30 & 6.82 & 0.34 & 2.58 & 7.15 & 21.1 & 0.53 & $2.09 \mathrm{E}-03$ & $5.10 \mathrm{E}-05$ & $6.50 \mathrm{E}-03$ & 0.16 & 3.38 & 2.73 \\
\hline $\begin{array}{l}\text { Sondeo Romilla la Nueva } \\
37^{\circ} 10.0216^{\prime} \mathrm{N} ; 3^{\circ} 48.8567^{\prime} \mathrm{W}\end{array}$ & SRN & W & 740 & 32 & 7.3 & 6.13 & 14.3 & 8.80 & 15.5 & 0.41 & 2.72 & 18.9 & 23.2 & 0.45 & $5.13 \mathrm{E}-03$ & 8.92E-05 & $4.25 \mathrm{E}-02$ & 0.17 & 4.26 & 4.48 \\
\hline $\begin{array}{c}\text { Sierra Elvira } \\
37^{\circ} 13.7033^{\prime} \mathrm{N} ; 3^{\circ} 43.3372^{\prime} \mathrm{W}\end{array}$ & SE & $S$ & & 30 & 6.9 & 3.82 & 7.80 & 5.28 & 10.8 & 0.27 & 3.77 & 12.4 & 11.6 & 0.43 & $3.74 \mathrm{E}-03$ & $1.35 \mathrm{E}-04$ & b.d.l & 0.11 & 2.52 & 2.93 \\
\hline $\begin{array}{c}\text { Banos Alhama de Granada } \\
37^{\circ} 01.1221^{\prime} \mathrm{N} ; 3^{\circ} 58.9970^{\prime} \mathrm{W}\end{array}$ & BAG & S & & 40 & 7.4 & 1.13 & 2.44 & 1.30 & 1.45 & 0.15 & 3.59 & 1.39 & 2.05 & 0.55 & $6.85 \mathrm{E}-04$ & $3.49 \mathrm{E}-04$ & b.d.1 & 0.04 & 0.67 & 0.02 \\
\hline $\begin{array}{c}\text { Banos Nuevo Alhama de Granada } \\
37^{\circ} 01.3410^{\prime} \mathrm{N} ; 3^{\circ} 58.7548^{\prime} \mathrm{W}\end{array}$ & BNAG & S & & 39 & 7.2 & 1.24 & 2.63 & 1.36 & 1.87 & 0.17 & 2.89 & 1.89 & 2.60 & 0.72 & $6.95 \mathrm{E}-04$ & $2.71 \mathrm{E}-04$ & 4.42E-04 & 0.06 & 0.73 & 0.08 \\
\hline $\begin{array}{c}\text { Alicun de las Torres } \\
37^{\circ} 30.5418^{\prime} \mathrm{N} ; 3^{\circ} 06.4172^{\prime} \mathrm{W}\end{array}$ & AT & S & & 34 & 6.7 & 2.24 & 8.25 & 4.35 & 2.32 & 0.12 & 2.06 & 2.32 & 11.4 & 0.31 & $8.89 \mathrm{E}-04$ & $1.38 \mathrm{E}-04$ & b.d.l. & 0.11 & 1.83 & 0.87 \\
\hline $\begin{array}{c}\text { Banos de Zujar } \\
37^{\circ} 34.556^{\prime} \mathrm{N}, 2^{\circ} 49.463^{\prime} \mathrm{W}\end{array}$ & $\mathrm{BZ}$ & W & - & 35 & 6.8 & 12.8 & 15.8 & 8.01 & 56.1 & 0.62 & 2.91 & 61.4 & 23.3 & 0.62 & $1.71 \mathrm{E}-02$ & $1.98 \mathrm{E}-04$ & $5.74 \mathrm{E}-03$ & 0.23 & 6.80 & 3.03 \\
\hline
\end{tabular}

Table 1: Sample details including sample location and water chemistry. Location of sampling points refer to WGS84 system. Type of water points: S = spring; $\mathrm{W}=$ well. EC is electrical conductivity in $\mathrm{mS} / \mathrm{cm}$. Concentrations of dissolved elements and TDS are expressed in mmol/kg of solution and in mg/L respectively. CBE (Charge Balance Error) is expressed in \%. b.d.1 = below detection limit. 


\begin{tabular}{|c|c|c|c|c|c|c|c|c|c|c|c|c|c|c|}
\hline Sample & Calcite & Dolomite & Gypsum & Anhydrite & Halite & Quartz & Chalcedony & $\begin{array}{c}\text { K- } \\
\text { feldspar }\end{array}$ & Kaolinite & Albite & Anorthite & $\begin{array}{c}\text { Ca- } \\
\text { Mont. }\end{array}$ & $\mathrm{CO}_{2}(\mathrm{~g})$ & $f \mathrm{CO}_{2}(\mathrm{~g})$ \\
\hline $\begin{array}{l}\text { Contacts metam. } \\
\text { complexes }\end{array}$ & & & & & & & & & & & & & & \\
\hline BSL & -0.61 & -1.39 & -1.40 & -1.61 & -4.66 & 1.14 & 0.74 & 3.15 & 8.02 & 1.65 & -1.03 & 7.96 & 0.01 & 1.03 \\
\hline $\mathrm{CL}$ & 0.32 & 0.34 & -0.63 & -0.86 & -3.21 & 1.25 & 0.83 & 5.42 & 10.44 & 3.90 & 1.93 & 11.01 & -0.02 & 0.96 \\
\hline BAA & 0.02 & 0.27 & -1.83 & -1.89 & -6.17 & 0.74 & 0.42 & 0.14 & 2.52 & -0.52 & -2.79 & 1.65 & -1.21 & 0.061 \\
\hline $\begin{array}{l}\text { Graben into Alp. } \\
\text { Complex }\end{array}$ & & & & & & & & & & & & & & \\
\hline BUC & 0.41 & 0.75 & -1.19 & -1.42 & -8.46 & 0.40 & -0.01 & -0.67 & 3.23 & -2.31 & -2.68 & 1.90 & -2.23 & 0.006 \\
\hline BUG & 0.16 & 0.23 & -1.21 & -1.44 & -6.52 & 0.37 & -0.05 & 0.18 & 4.36 & -1.25 & -2.25 & 3.05 & -1.95 & 0.011 \\
\hline Evaporitic basin & & & & & & & & & & & & & & \\
\hline $\mathrm{BM}$ & 0.43 & 0.78 & -0.37 & -0.57 & -6.33 & 0.54 & 0.15 & 0.56 & 4.06 & -0.57 & -1.42 & 3.14 & -2.22 & 0.006 \\
\hline $\mathrm{SF}$ & 0.21 & 0.34 & -0.07 & -0.22 & -6.13 & 0.48 & 0.12 & 0.37 & 4.18 & -0.73 & -1.20 & 3.23 & -1.79 & 0.016 \\
\hline SRN & 0.39 & 0.74 & -0.06 & -0.25 & -5.35 & 0.52 & 0.14 & 1.15 & 5.12 & 0.25 & -0.35 & 4.34 & -2.10 & 0.008 \\
\hline $\mathrm{SE}$ & 0.04 & 0.07 & -0.43 & -0.63 & -5.65 & 0.52 & 0.13 & 0.91 & 5.65 & 0.00 & -0.81 & 4.81 & -1.60 & 0.025 \\
\hline BAG & 0.32 & 0.62 & -1.30 & -1.44 & -7.41 & 0.48 & 0.12 & -0.39 & 2.49 & -1.80 & -2.54 & 1.31 & -1.95 & 0.011 \\
\hline BNAG & 0.06 & 0.06 & -1.18 & -1.33 & -7.17 & 0.61 & 0.25 & 0.07 & 3.20 & -1.29 & -2.26 & 2.24 & -1.87 & 0.013 \\
\hline AT & -0.32 & -0.73 & -0.37 & -0.55 & -7.03 & 0.31 & -0.06 & -0.83 & 4.02 & -1.99 & -2.45 & 2.63 & -1.63 & 0.024 \\
\hline $\mathrm{BZ}$ & 0.01 & -0.07 & -0.10 & -0.27 & -4.32 & 0.62 & 0.25 & 2.00 & 6.90 & 1.52 & 0.84 & 6.46 & -1.62 & 0.024 \\
\hline
\end{tabular}

Table 2: Saturation indices (SI) of the main mineral phases of interest in the investigated area. $\mathrm{CO}_{2}(\mathrm{~g})$ corresponds to the log 10 of $\mathrm{CO}_{2}$ fugacity $\left(f \mathrm{CO}_{2}\right)$. SI were calculated with the PHREEQC code at the outlet temperature (measured in the field). 


\begin{tabular}{|c|c|c|c|c|c|c|c|c|c|c|}
\hline Sample & $\begin{array}{r}\mathrm{O}_{2} \\
\mathrm{cc} / \mathrm{L}\end{array}$ & $\begin{array}{l}\mathrm{N}_{2} \\
\mathrm{cc} / \mathrm{L}\end{array}$ & $\begin{array}{l}\mathrm{CO}_{2} \\
\mathrm{cc} / \mathrm{L}\end{array}$ & $\begin{array}{l}\mathrm{pCO}_{2} \\
\text { atm }\end{array}$ & $\begin{array}{c}\mathbf{H}_{2} \\
\mathbf{p p m}\end{array}$ & $\begin{array}{r}\text { CO } \\
\text { ppm }\end{array}$ & $\begin{array}{l}\mathrm{CH}_{4} \\
\mathrm{ppm}\end{array}$ & $\begin{array}{c}\text { TDIC } \\
\text { mmol/L }\end{array}$ & $\begin{array}{c}\delta^{13} \mathbf{C}_{(\text {TDIC })} \\
\% \text { o }\end{array}$ & $\begin{array}{c}\boldsymbol{\delta}^{13} \mathbf{C}_{(\mathrm{CO} 2)} \\
\%\end{array}$ \\
\hline Contacts metam. complexes & & & & & & & & & & \\
\hline BSL & 0.07 & 1.74 & 576 & 0.78 & $6.82 \mathrm{E}-04$ & $2.88 \mathrm{E}-04$ & $5.29 \mathrm{E}-03$ & 46.6 & -5.2 & -6.6 \\
\hline $\mathrm{CL}$ & 0.08 & 1.94 & 597 & 0.71 & b.d.l & $1.41 \mathrm{E}-04$ & $8.66 \mathrm{E}-05$ & 63.0 & -4.7 & -7.5 \\
\hline BAA & 1.49 & 12.1 & 39.4 & 0.088 & $9.72 \mathrm{E}-04$ & $3.16 \mathrm{E}-04$ & $1.53 \mathrm{E}-02$ & 9.1 & -9.0 & -13.6 \\
\hline $\begin{array}{c}\text { Graben into Alp. Complex } \\
\text { BUG }\end{array}$ & 1.57 & 18.6 & 16.2 & 0.020 & b.d.1 & 2.69E-05 & $6.36 \mathrm{E}-04$ & 4.6 & -9.0 & -16.2 \\
\hline Evaporitic basin & & & & & & & & & & \\
\hline $\mathrm{SF}$ & 1.81 & 17.0 & 9.51 & 0.017 & b.d.l & $3.51 \mathrm{E}-05$ & $1.38 \mathrm{E}-02$ & 2.9 & -1.5 & -6.6 \\
\hline $\mathrm{SE}$ & 0.13 & 18.3 & 22.2 & 0.033 & b.d.1 & b.d.1 & $2.39 \mathrm{E}-04$ & 4.5 & -8.8 & -14.5 \\
\hline BAG & 0.67 & 17.6 & 10.7 & 0.020 & b.d.l & b.d.l & 7.43E-04 & 3.8 & -7.6 & -13.3 \\
\hline AT & 0.44 & 16.7 & 27.0 & 0.044 & $1.10 \mathrm{E}-03$ & 7.03E-05 & $2.48 \mathrm{E}-05$ & 2.7 & -5.0 & -9.8 \\
\hline $\mathrm{BZ}$ & 0.62 & 13.8 & 16.3 & 0.027 & $1.51 \mathrm{E}-03$ & $2.02 \mathrm{E}-04$ & $3.37 \mathrm{E}-02$ & 3.5 & -3.4 & -8.4 \\
\hline
\end{tabular}

Table 3: Dissolved gases and carbon isotopic composition of the selected investigated thermal waters. TDIC was calculated using PHREEQC. b.d.l = below detection limit. 


\begin{tabular}{|c|c|c|c|c|c|c|c|c|c|}
\hline \multirow[b]{2}{*}{ Sample } & \multirow[b]{2}{*}{$\begin{array}{l}\text { Outlet } \\
\text { temp. }\end{array}$} & \multicolumn{4}{|c|}{$\mathrm{SiO}_{2}$-Quartz } & \multicolumn{2}{|c|}{$\mathrm{SiO}_{2}$-chalcedony } & \multirow{2}{*}{$\begin{array}{c}\mathrm{Ca} / \mathrm{Mg} \\
\text { Chiodini } \\
\text { (1995a) }\end{array}$} & \multirow{2}{*}{$\begin{array}{c}\mathrm{fCO}_{2} \\
\begin{array}{c}\text { Chiodini } \\
(1995 \mathrm{a})\end{array}\end{array}$} \\
\hline & & $\begin{array}{l}\text { Michard } \\
\text { (1979) }\end{array}$ & $\begin{array}{c}\text { Verma } \\
(2000 b)\end{array}$ & $\begin{array}{c}\text { Fournier } \\
\text { and Potter } \\
(\mathbf{1 9 8 2 )}\end{array}$ & $\begin{array}{c}\text { Fournier } \\
(1977)\end{array}$ & $\begin{array}{l}\text { Arnorsson } \\
\text { (1983) }\end{array}$ & $\begin{array}{l}\text { Michard } \\
(\mathbf{1 9 9 0})\end{array}$ & & \\
\hline \multicolumn{10}{|l|}{$\begin{array}{l}\text { Contacts metam. } \\
\text { complexes }\end{array}$} \\
\hline BSL & 26 & 145 & 143 & 146 & 139 & 115 & 102 & 86 & 16.34 \\
\hline CL & 21 & 133 & 130 & 134 & 129 & 103 & 92 & 88 & 23.82 \\
\hline BAA & 51 & 128 & 124 & 128 & 127 & 97 & 87 & 60 & 5.63 \\
\hline \multicolumn{10}{|l|}{$\begin{array}{l}\text { Graben into Alp. } \\
\text { Complex }\end{array}$} \\
\hline BUC & 25 & 57 & 47 & 57 & 62 & 26 & 24 & 75 & 0.54 \\
\hline BUG & 23 & 52 & 42 & 51 & 58 & 21 & 20 & 74 & 0.66 \\
\hline \multicolumn{10}{|l|}{ Evaporitic basin } \\
\hline $\mathrm{BM}$ & 30 & 76 & 67 & 76 & 79 & 45 & 41 & 81 & 0.08 \\
\hline $\mathrm{SF}$ & 39 & 83 & 74 & 83 & 85 & 52 & 47 & 87 & 0.05 \\
\hline SRN & 32 & 76 & 67 & 76 & 79 & 45 & 41 & 75 & 0.04 \\
\hline SE & 30 & 74 & 66 & 75 & 78 & 43 & 40 & 71 & 0.16 \\
\hline BAG & 40 & 84 & 76 & 85 & 86 & 53 & 48 & 89 & 0.74 \\
\hline BNAG & 39 & 96 & 89 & 97 & 97 & 65 & 59 & 91 & 0.38 \\
\hline AT & 34 & 61 & 52 & 61 & 66 & 30 & 28 & 88 & 0.05 \\
\hline BZ & 35 & 90 & 82 & 90 & 91 & 58 & 53 & 84 & 0.06 \\
\hline
\end{tabular}

Table 4: Temperature $\left({ }^{\circ} \mathrm{C}\right)$ obtained with selected geothermometers and fugacity of $\mathrm{CO}_{2}\left(f \mathrm{CO}_{2}\right)$ obtained with Chiodini et al. (1995a)'s geobarometer. 

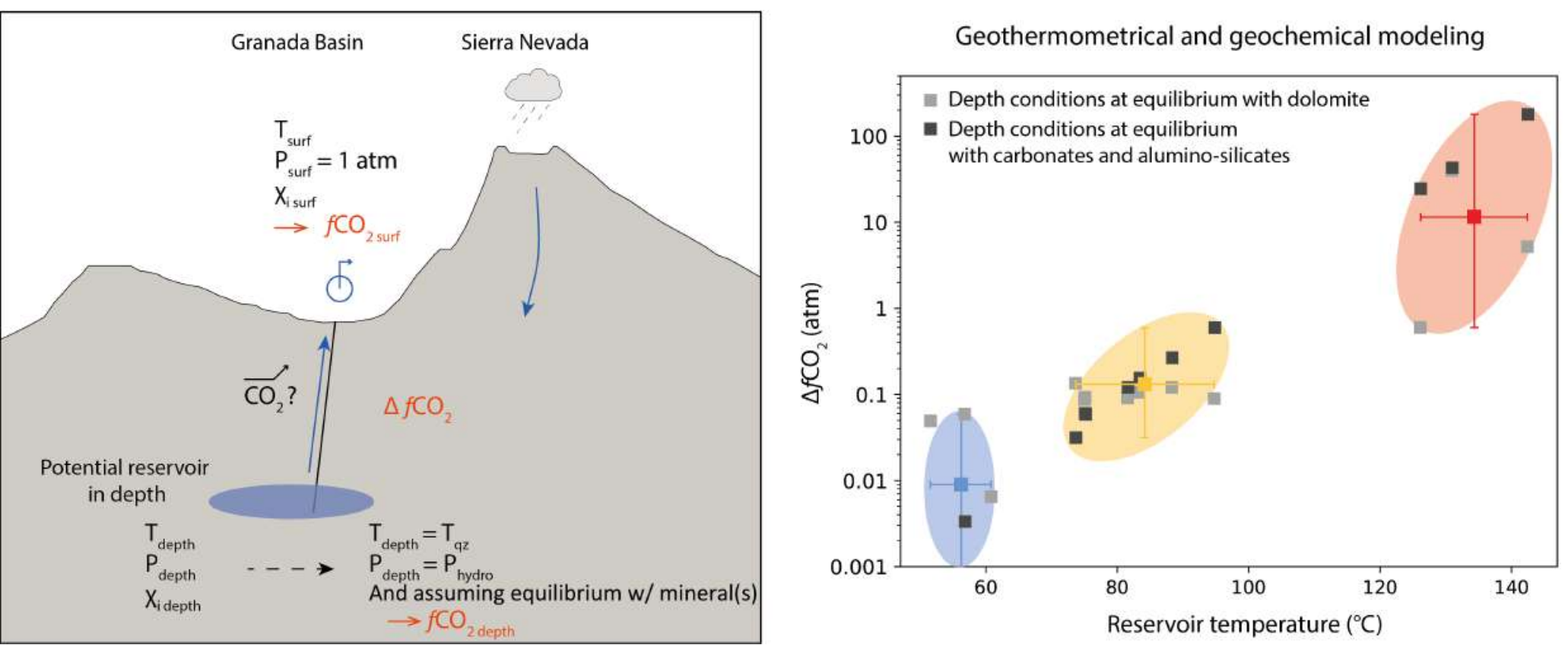